\title{
Hi-JAK-ing The Ubiquitin System: The Design and Physicochemical Optimisation of JAK PROTACs
}

Rishi R. Shah,, ${ }^{+, \neq},{ }^{+}$Joanna M. Redmond, ${ }^{\dagger}$ Andrei Mihut, ${ }^{\dagger}$ Malini Menon, ${ }^{\dagger}$ John P. Evans, ${ }^{\dagger}$ John A. Murphy, ${ }^{\ddagger}$ Michelle A. Bartholomew, ${ }^{\dagger}$ and Diane M. Coe. ${ }^{\dagger}$

${ }^{\dagger}$ Medicines Research Centre, GlaxoSmithKline, Stevenage, SG1 2NY, United Kingdom

${ }^{\ddagger}$ Department of Pure and Applied Chemistry, WestCHEM, University of Strathclyde, 295 Cathedral Street, Glasgow, G1 1XL, United Kingdom

\section{Abstract}

PROTACs have recently emerged as a novel paradigm in drug discovery. They can hijack existing biological machinery to selectively degrade proteins of interest, in a catalytic fashion. Here we describe the design, optimisation and biological activity of a set of novel PROTACs targeting the Janus kinase family (JAK1, JAK2, JAK3 and TYK2) of proximal membrane-bound proteins. The JAK family proteins display membrane localisation by virtue of their association with cytoplasmic tails of cytokine receptors and there are no reports of a successful PROTAC strategy being deployed against this class of proteins. JAK PROTACs from two distinct JAK chemotypes were designed optimising the physicochemical properties for each template to enhance cell permeation. These PROTACs are capable of inducing JAK1 and JAK2 degradation, demonstrating an extension of the PROTAC methodology to an unprecedented class of protein targets. A number of the known ligase binders were explored, and it was found that PROTACs bearing an inhibitor of apoptosis protein (IAP) ligand induced significantly more JAK degradation over Von Hippel-Lindau (VHL) and Cereblon (CRBN) PROTACs. In addition, the mechanism of action of the JAK PROTACs was elucidated, and it was confirmed that JAK degradation was both IAP- and proteasome-dependant.

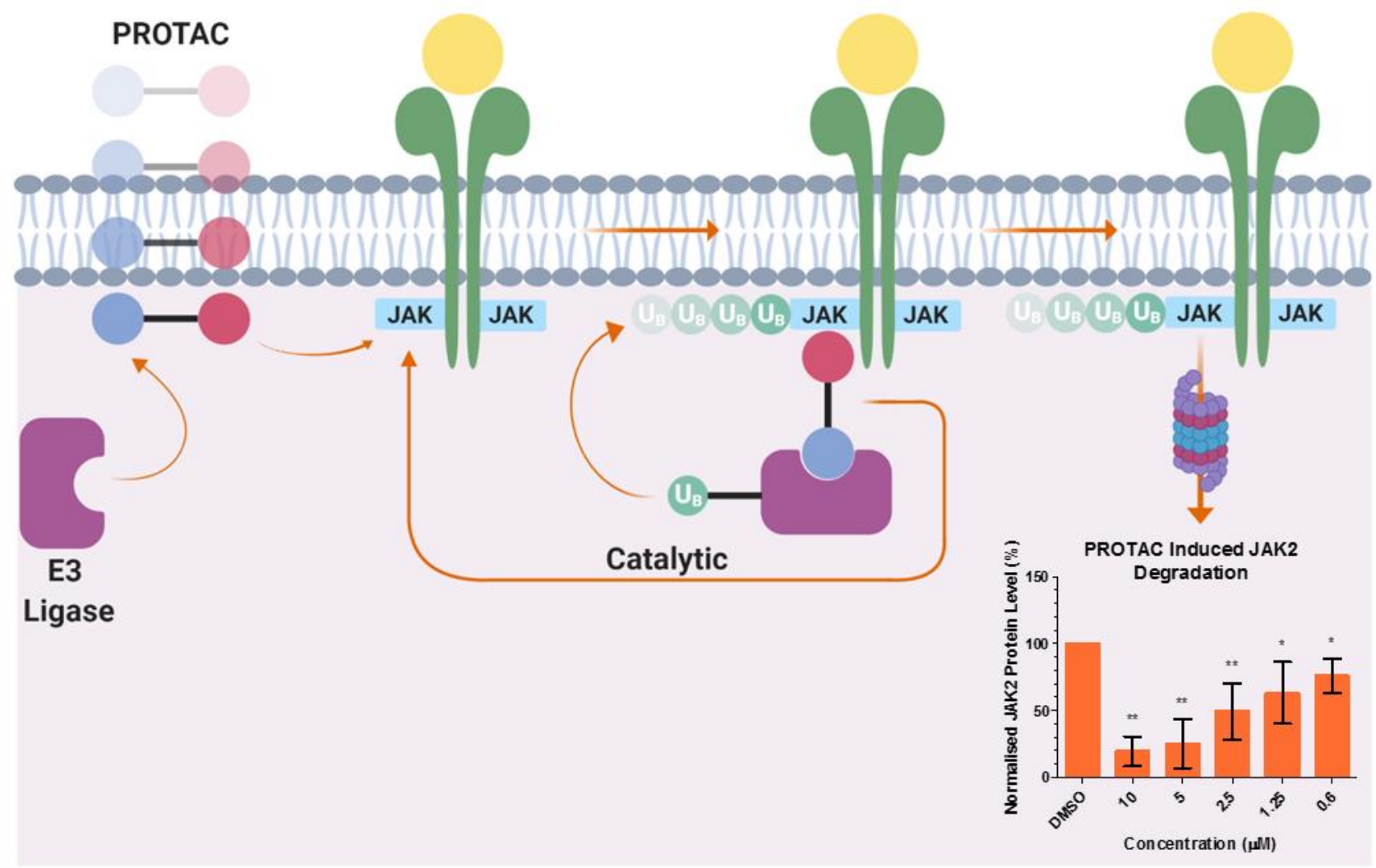




\section{Introduction}

Communication between cells is essential for cell development, host defence and tissue and organism homeostasis. The Janus kinase/signal transducers and activators of transcription (JAK-STAT) pathway provides an exquisite solution to cell communication from transmembrane receptors directly to the nucleus. The proximal membrane-bound kinase, comprised of four known isoforms (JAK1, JAK2, JAK3 and TYK2) has been implicated in a multitude of diseases from cancer to inflammatory diseases. ${ }^{1}$ We proposed that silencing components of the JAK-STAT signalling pathway by the degradation of a subset of JAK proteins may provide novel therapeutics or biological probes. Whilst members of the proximal membrane-bound JAK family have been downregulated by a small molecule pan-JAK inhibitor, ${ }^{2}$ they are yet to be degraded via a proteolysis targeting chimera (PROTAC) approach. PROTACs have been deployed to induce degradation of various proteins. ${ }^{3,4,5,6,7}$ Whilst PROTAC-mediated degradation of membrane-bound proteins such as EGFR have been degraded, ${ }^{8}$ proximal membrane-bound protein degradation has not been reported. Therefore, the successful degradation of the JAK proteins would demonstrate an extension of the cutting edge PROTAC methodology to an unprecedented class of protein targets. Within this proof of concept study, we disclose the design of the first PROTACs, derived from two distinct chemotypes, capable of inducing JAK degradation. Moreover, we explore the physicochemical optimisation of cell penetrant JAK PROTACs, and how their physicochemical properties impact degradation efficiency.

\section{Results and Discussion}

2.1 Selecting A Warhead. When selecting a particular chemotype from which to generate PROTACs, it is imperative that target affinity, physicochemical properties of the warhead and ligation vector are all adequately considered. As such, two chemotypes were selected based on the aforementioned properties (Figure 1a). The in-house designed Pyrimidine 1 JAK inhibitor exhibits a JAK1, 2, 3 inhibitory profile, displaying high potency across the JAK1 - 3 isoforms within the biochemical assay at $K_{\mathrm{m}}$ concentrations of ATP (Table 1). The parent compounds were further characterised within a cellular context in an interleukin 2 (IL2) peripheral blood mononuclear cell (PBMC) assay, which quantifies the extent of JAK1 and JAK3 inhibition upon IL2 stimulation, measuring downstream interferon gamma (IFN $\gamma$ ) production. Pyrimidine 1 inhibited IFN $\gamma$ signalling through JAK1/JAK3 inhibition $\left(\mathrm{pIC}_{50}=8.1\right)$. A second JAK inhibitor, based on a Quinoxaline template $\mathbf{2}$, was selected as it possessed a more pan-JAK profile than other compounds within the same series such as NVP-BSK805, ${ }^{9,10,11}$ albeit it maintains a JAK2-biased profile. Quinoxaline 2 displayed moderate potency within our IL2 PBMC assay $\left(\mathrm{pIC}_{50}=\right.$ 6.5). From a computational model of Pyrimidine 1 docked within JAK2, two clear exit vectors from the binding site were identified, from which to generate PROTACs (Figure 1b). Moreover, the computational model of Quinoxaline $\mathbf{2}$ positioned the morpholine moiety within a solvent exposed region, and it was hypothesised that morpholine could be exchanged for a piperazine to provide a point of ligation. 

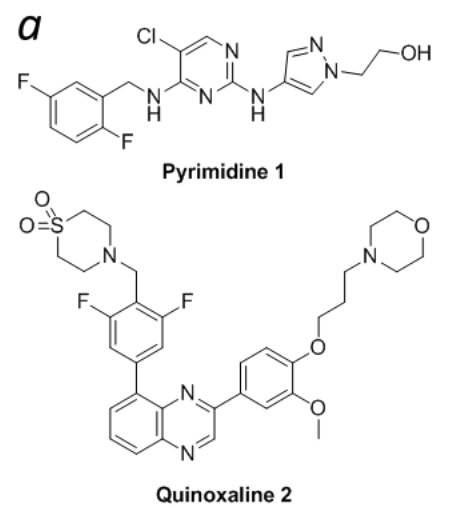

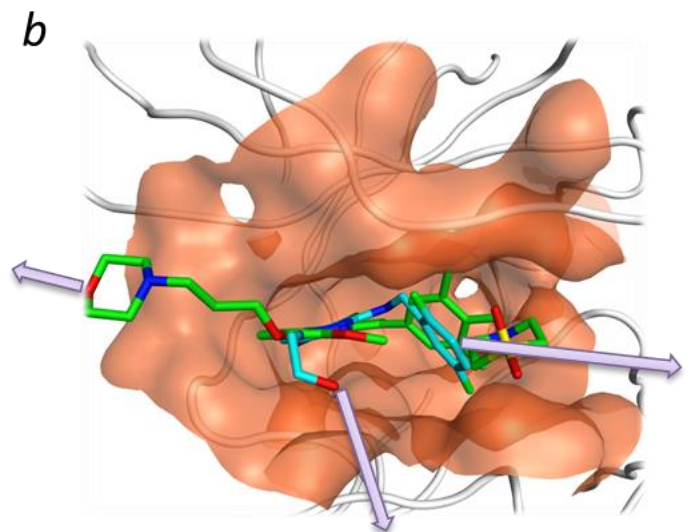

Figure 1 a) The chemical structures of Pyrimidine 1 and Quinoxaline 2. b) An overlay of Pyrimidine 1 (blue), Quinoxaline 2 (green), within JAK2. The lilac arrows indicate potential ligation vectors. Dockings were carried out in MOE using a Triangle Matcher protocol against closely related crystal structures of the respective ligands. Pyrimidine 1 docking utilised an unpublished crustal structure, and Quinoxaline 2 made use PDB: 3KRR as the crystal structure.

\begin{tabular}{|c|c|c|c|c|c|c|c|c|c|}
\hline \multirow[b]{2}{*}{ Compound } & \multirow[b]{2}{*}{ HBD } & \multirow{2}{*}{$\begin{array}{l}\text { Chrom } \\
\text { LogD }_{7.4}\end{array}$} & \multirow{2}{*}{$\begin{array}{l}\text { PSA } \\
\left(\AA^{2}\right)\end{array}$} & \multicolumn{4}{|c|}{$\mathrm{plC}_{50}$} & \multirow{2}{*}{$\begin{array}{c}\text { JAK1 } \\
\text { Drop- } \\
\text { Off } \\
\text { (Fold) }\end{array}$} & \multirow{2}{*}{$\begin{array}{c}\text { JAK3 } \\
\text { Drop- } \\
\text { Off } \\
\text { (Fold) }\end{array}$} \\
\hline & & & & JAK1 & JAK2 & JAK3 & $\begin{array}{c}\text { IL2 } \\
\text { PBMC }\end{array}$ & & \\
\hline Pyrimidine 1 & 3 & 3.5 & 88 & $>9.8$ & 9.5 & 9.0 & 8.1 & $<50$ & 8 \\
\hline Quinoxaline 2 & 0 & 6.0 & 131 & 8.1 & 9.6 & 8.1 & 6.5 & 40 & 40 \\
\hline
\end{tabular}

Table 1 Overview of the physicochemical properties and binding inhibition data associated with Pyrimidine 1 and Quinoxaline 2. $\mathrm{plC}_{50}$ values are quoted as a mean of multiple, separate experiments $(n \geq 2)$. Polar surface area (PSA) was calculated using the Ertl et al. calculation method. ${ }^{12} \mathrm{HBD}=\mathrm{H}$-bond donor count. Quinoxaline $\mathbf{2}$ was tested as a formic acid salt.

2.2 Design and Optimisation of Cell Permeable JAK PROTACs. Whilst the adoption of all-small molecule PROTACs has led to an improvement in cell permeation over their peptidic counterparts, PROTACs occasionally require high concentrations to achieve maximal protein degradation. ${ }^{13,14}$ Since PROTACs intrinsically fall outside of Lipinski's rule of 5 (Ro5) space, ${ }^{15,16}$ a set of guidelines developed to achieve oral absorption known as 'beyond the rule of 5' (bRo5) were considered in our design of cell penetrant PROTACs. ${ }^{17,18,19}$ Whilst these guidelines were generated to achieve oral absorption with larger small-molecules, the boundaries of physicochemical parameters, such as $\mathrm{H}$-bond donor (HBD) count $(\leq 6)$ and a ChromLog $\mathrm{D}_{7.4}$ of $4-6$ suggested in these guidelines were deemed potentially useful in our attempts to enhance cell permeation. ${ }^{18,20}$ For the purposes of our work, PROTAC optimisation was focused on increasing permeability as a driver of activity in an in vitro cellular environment.

PROTACs can be dissected into three distinct components: the warhead, ligase binder and linker. Variation of these constituents would modulate the overall physicochemical properties of our PROTACs, allowing evaluation of occupied physicochemical space. Of the selected JAK warheads, Quinoxaline 2 possessed fewer HBDs, and an increased ChromLogD ${ }_{7.4}$ over Pyrimidine 1 (Table 1). Consequently, the HBD count of PROTACs derived from Quinoxaline $\mathbf{2}$ would only arise from the linker and ligase binder. Conversely, Pyrimidine 1 contributed 2 HBDs to the overall PROTAC, potentially resulting in diminished permeability in contrast to analogous Quinoxaline $\mathbf{2}$ derived PROTACs. With the two JAK chemotypes selected, the focus was shifted towards exploring different classes of E3 ligase binders. Three distinct E3 ligase binders were chosen; inhibitor of apoptosis protein (IAP), ${ }^{21}$ Von 
Hippel-Lindau $(\mathrm{VHL})^{22}$ and Cereblon (CRBN). ${ }^{23}$ IAP, VHL and CRBN ligands confer differing physicochemical attributes, with ChromLog $D_{7.4}$ and $H B D$ count decreasing from acetylated-IAP (ChromLogD $7.4=3.6, \mathrm{HBD}=4$ ) to acetylated-VHL (ChromLogD ${ }_{7.4}=2.5, \mathrm{HBD}=3$ ) to acetylated-CRBN (ChromLogD ${ }_{7.4}=0.2, \mathrm{HBD}=2$ ) (Table S1). Additionally, the linker can have a profound effect on the PROTACs' physicochemical properties, and consequently modulate cell permeability. Since the optimum linker length and composition for JAK degradation was unknown, an assortment of all carbon and polyethylene glycol (PEG) linkers were sought, from $10-20$ atoms in length (Figure S1). A wide range of physicochemical space with respect to HBD count and ChromLog $D_{7.4}$ was explored, both encompassing, and exceeding the in-house and literature guidelines (ChromLog $\mathrm{D}_{7.4}$ range: 3.6 - 7.7; HBD range: 2 - 6) (Figure S2). The JAK PROTAC library maintained a PSA $\leq 250 \AA^{2},{ }^{17}$ and so PSA was not considered to be a critical parameter for optimisation in this case.

2.3 Synthesis of JAK PROTACs. Following the synthesis of the parent compounds (Schemes S1 - S5), the appropriate linkers and ligase binders were appended (Scheme 1). Amide couplings were performed between both the 4-PEG linked pyrimidine 3, and 10-carbon linked pyrimidine 4 and with Boc-IAP 5. Addition of TFA generated JP-1 6 and JP-2 $730-36 \%$ yield. To synthesise the benzylic pyrimidine series PROTACs, pyrimidine phenol 8 was coupled to 3-PEG linked Boc-IAP 9, and subsequent Boc-deprotection provided JP-3 10 in a $47 \%$ yield over the two steps. The pyrimidinephenol core was alkylated with the 10-carbon ester $\mathbf{1 1}$, and hydrolysis with $\mathrm{K}_{2} \mathrm{CO}_{3}$ afforded acid $\mathbf{1 2}$ in a $60 \%$ yield. The 10-carbon pyrimidine acid 12 was exposed to HATU amide coupling conditions, with Boc-IAP 5, and Boc-deprotection furnished JP-4 13 in a 54 \% yield.

A similar strategy was employed to synthesise the quinoxaline PROTACs, in that quinoxaline $\mathbf{1 4}$ was tethered to 3-PEG linked Boc-IAP 9, following Boc-deprotection JP-5 15 was produced in a 76 \% yield over two steps (Scheme 2). Additionally, an amide coupling was conducted between Boc-IAP 5 and 10-carbon linked quinoxaline acid 16, and subsequent treatment with TFA afforded JP-6 17 in a $54 \%$ yield over the two steps. 

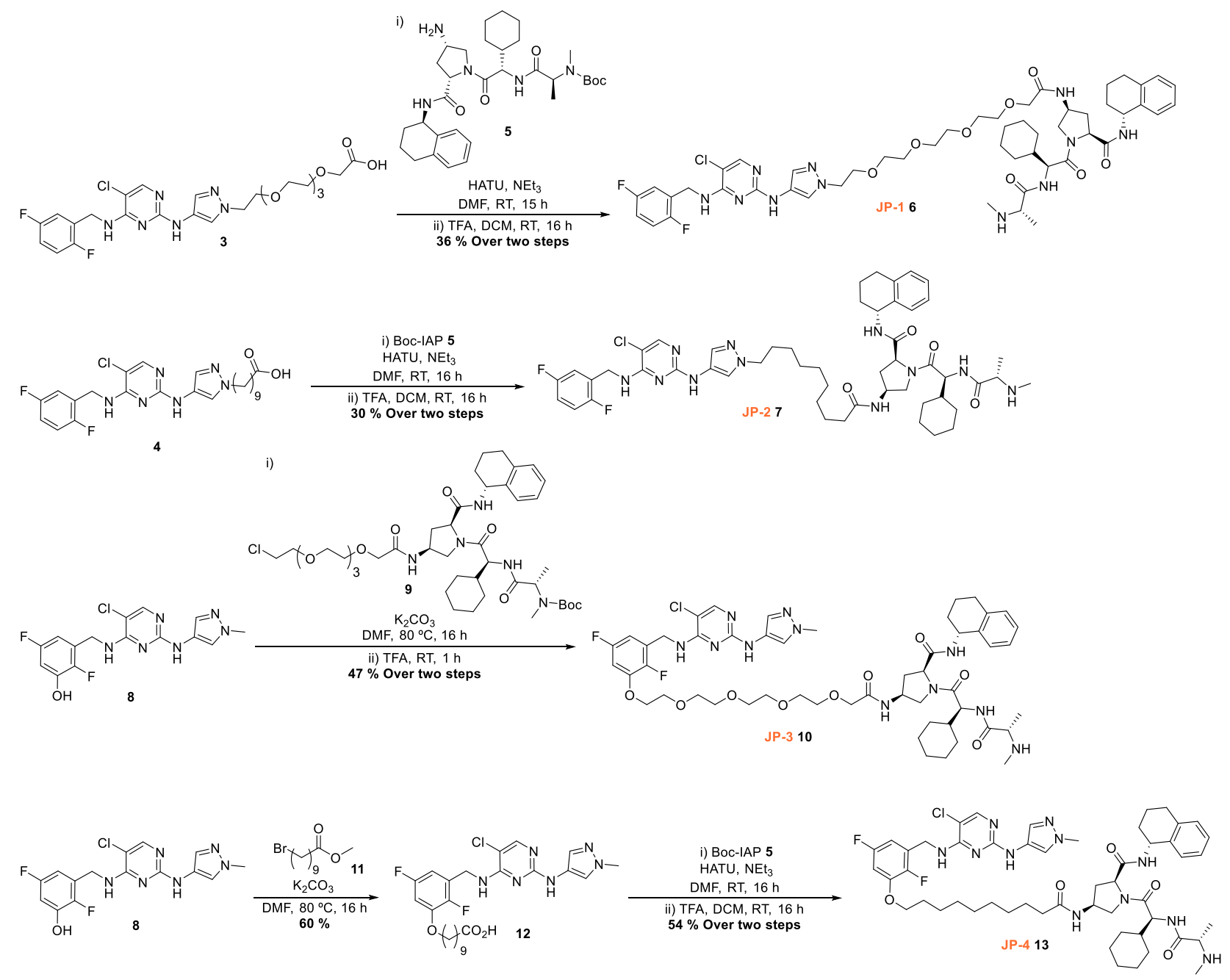

Scheme 1 The synthesis of the pyrimidine series IAP PROTACs.

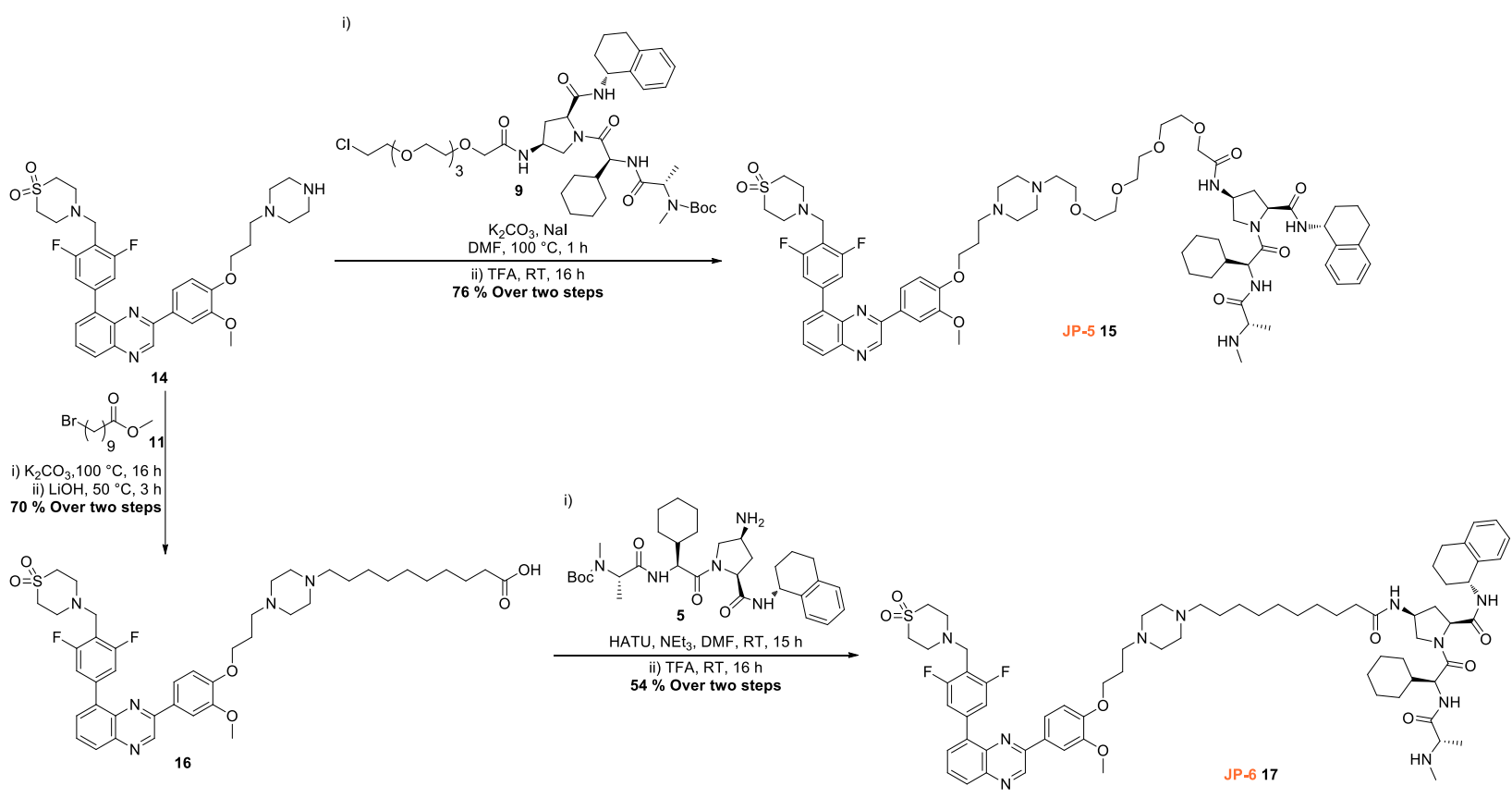

Scheme $\mathbf{2}$ The synthesis of the quinoxaline series IAP PROTACs. 
2.4 Cellular Screening of JAK PROTACs. Evaluation of the PROTACs within a JAK biochemical assay, showed that ligation from the three different vectors of the two JAK warheads was tolerated by each JAK isoform, although a decrease in biochemical potency of the PROTACs, relative to the JAK warheads, was observed (Table S2 - S4).

To assess the impact of the PROTAC library's physicochemical properties on cell permeability, a permeability measure was required. Typically for small molecule inhibitors, moving from the isolated biochemical assay to a cellular environment such as the IL2 PBMC assay results in a drop-off in potency. ${ }^{24}$ Since classic permeability assays designed for oral bioavailability did not provide useful data from a cellular context, the drop-off in potencies of JAK1 and JAK3 biochemical assays to the cell were used as a permeability surrogate (drop-off $=10^{\wedge}\left(J A K 1\right.$ or JAK3 $\mathrm{pIC}_{50}-\mathrm{IL} 2 \mathrm{PBMC}$ pIC $\left.\mathrm{C}_{50}\right)$ ). This is based on the assumption that a particularly large drop-off would be, at least in part, derived from poor access to the required intracellular compartment due to low membrane permeability. ${ }^{25}$ As significant JAK degradation was unlikely to occur within the $1 \mathrm{~h}$ incubation period within the IL2 PBMC assay, and therefore unable to positively impact the potency readout, the drop-off from the biochemical assay to the cell was deemed suitable as a permeability surrogate.

Analysis of our JAK PROTAC library revealed PROTACs derived from the pyrimidine series typically exhibited a greater drop-off from the isolated JAK1 and JAK3 biochemical assays to the cell as compared to analogous quinoxaline PROTACs (Figure 2). This was hypothesised to be a result of the quinoxaline-based PROTACs possessing fewer HBDs (HBD count $\leq 5$ ) than their pyrimidine counterparts ( $\mathrm{HBD}$ count $\leq 6$ ), and always expressed a higher ChromLog $\mathrm{D}_{7.4}$, thereby increasing permeability.

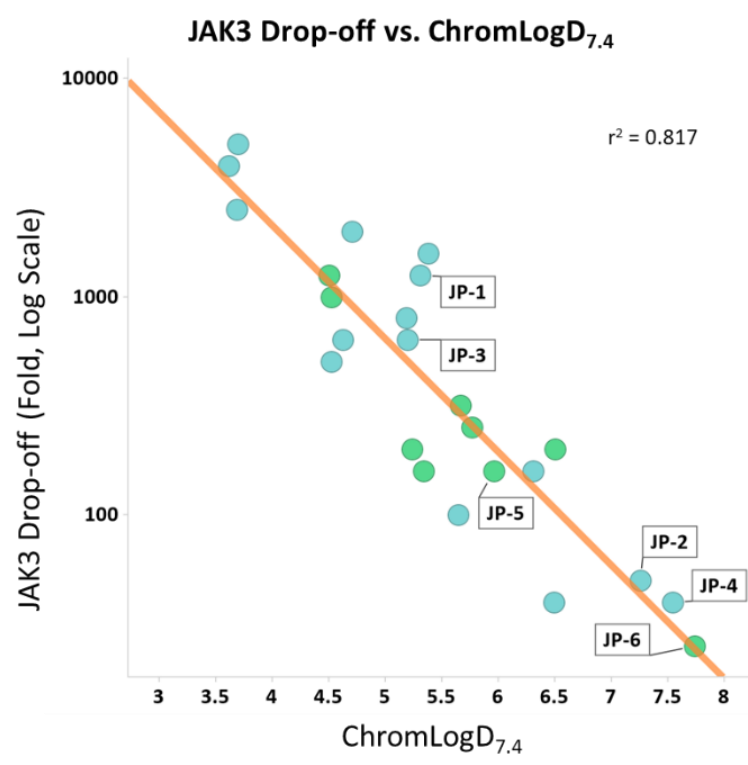

Figure 2 A plot of JAK3 drop-off (fold, log scale) vs. ChromLogD ${ }_{7.4}$ of the JAK PROTAC library. JP-1 - JP-6 are labelled. Pyrimidine series PROTACs are indicated by blue dots; quinoxaline series PROTACs are indicated by green dots. Orange line indicates straight line fit; $r^{2}=0.817$.

It was identified that IAP-recruiting PROTACs tended to demonstrate a reduced cellular drop-off from either JAK1 or JAK3, in comparison to the equivalent VHL and CRBN PROTACs. Within the pyrimidine series, HBD count decreases from IAP- (HBD count $=6)$ to VHL- (HBD count $=5)$ to CRBN-recruiting (HBD count $=4$ ) PROTACs. However, it is plausible to consider that a HBD within IAP is concealed via 
an intramolecular HB, and this concurred with IAP molecular modelling observations. As such, this may mask additional polarity, and IAP may behave as if it exhibits 5 HBDs rather than 6 . Conversely, an increase in ChromLog $D_{7.4}$ was observed from CRBN- to VHL- to IAP-recruiting PROTACs. The increased ChromLogD ${ }_{7.4}$ and potentially masked HBD count of IAP, translates to increased cell permeability, which is evident by the reduced potency drop-off from the biochemical to cellular assay. A similar trend was observed within the quinoxaline series in relation to the correlation between ChromLog $\mathrm{D}_{7.4}$ and HBD count, and reduced potency drop-off between the in vitro biochemical assay and cellular assay. As expected, switching a 4-PEG linker for a 10-carbon linker had a profound effect on the PROTACs physicochemical properties, typically increasing the ChromLog $D_{7.4}$ by approximately 170-fold, and reducing the biochemical to cell drop-off.

A panel of PROTACs was tested for their ability to degrade endogenous JAK1 and JAK2 by automated Western blotting. THP-1 cells (a human leukemia monocytic cell line), were chosen to probe the JAK PROTAC library's degradation aptitude as they are known to express IAP, VHL and CRBN. ${ }^{26}$ Additionally, both literature and in-house precedent identified THP-1 cells to be amenable to PROTAC activity screens. ${ }^{27}$ THP-1 cells express both JAK1 and JAK2, however, we were unable to detect JAK3 protein levels within our assay. Additionally, the THP-1 cells were not stimulated within the western blot assays, since stimulation is known to increase polyubiquitination of JAK2 via SOCS-1, which is not expressed in high levels when unstimulated. ${ }^{28}$ Furthermore, the western blot assays employed antibodies that solely detected unphosphorylated JAK. The most significant degradation was observed with PROTACs bearing an IAP E3 ligase binder. VHL- and CRBN-based PROTACs failed to induce JAK1 or JAK2 degradation within THP-1 cells (Tables S5 - S7). We identified six PROTACs, JP-1 - JP-6, capable of inducing JAK1 and/or JAK2 degradation. Furthermore, degradation was observed with both JAK warhead-derived PROTACs, and both vectors from PROTACs derived from the pyrimidine series.

JP-1 - JP-6 displayed enhanced degradation activity against JAK2 when compared to JAK1 (up to $35 \%$ ) (Figure 3) (Individual western blot visualisations are displayed in Figures S3 - S8). Whilst Quinoxaline 2 exhibited a JAK2 biased profile in the biochemical assays, the bias seems unlikely to be the sole cause of enhanced degradation activity at JAK2, since the Pyrimidine 1 derived PROTACs, which exhibit a more pan-JAK profile, also invoked greater JAK2 degradation. The differences in the number and availability of ubiquitination sites can result in an observed difference in activity. However, multiple predicted and experimentally verified ubiquitination sites are present in both JAK1 and JAK2. ${ }^{29,30,31,32}$ The JAK protein concentrations, as detected by the $24 \mathrm{~h}$ immunoblotting assay format, may be influenced by the longer half-life of JAK2, with the slower resynthesis of JAK2 resulting in lower detected concentrations in this assay ( $\mathrm{t}_{1 / 2}$ JAK1 in THP-1 cells $=10.6 \mathrm{~h}, \mathrm{t}_{1 / 2}$ JAK2 in THP-1 cells $=14.7$ h). ${ }^{33}$ Additionally, published findings on JAK1 and JAK2 propose both isoforms are localised exclusively in their proximal membrane-bound states, ${ }^{34}$ therefore reducing the likelihood that differential localisation of JAK1 and JAK2 plays a role in the enhanced JAK2 degradation efficiency. However, isoform selectivity has been observed through PROTAC generation of non-selective warheads with PROTACs targeting the BET faimily, ${ }^{35}$ and protein kinases, ${ }^{36,37}$ through modulation of linker length, E3 ligase binders and ligation point, thus altering the nature of PPIs and the cooperativity of the formed ternary complex. ${ }^{38}$ As such, the increased degradation of JAK2 over JAK1 could be a result of isoformspecific PPIs resulting in more positive cooperativity of the ternary complex involving JAK2 and IAP, over that of JAK1 and IAP. ${ }^{35}$ 

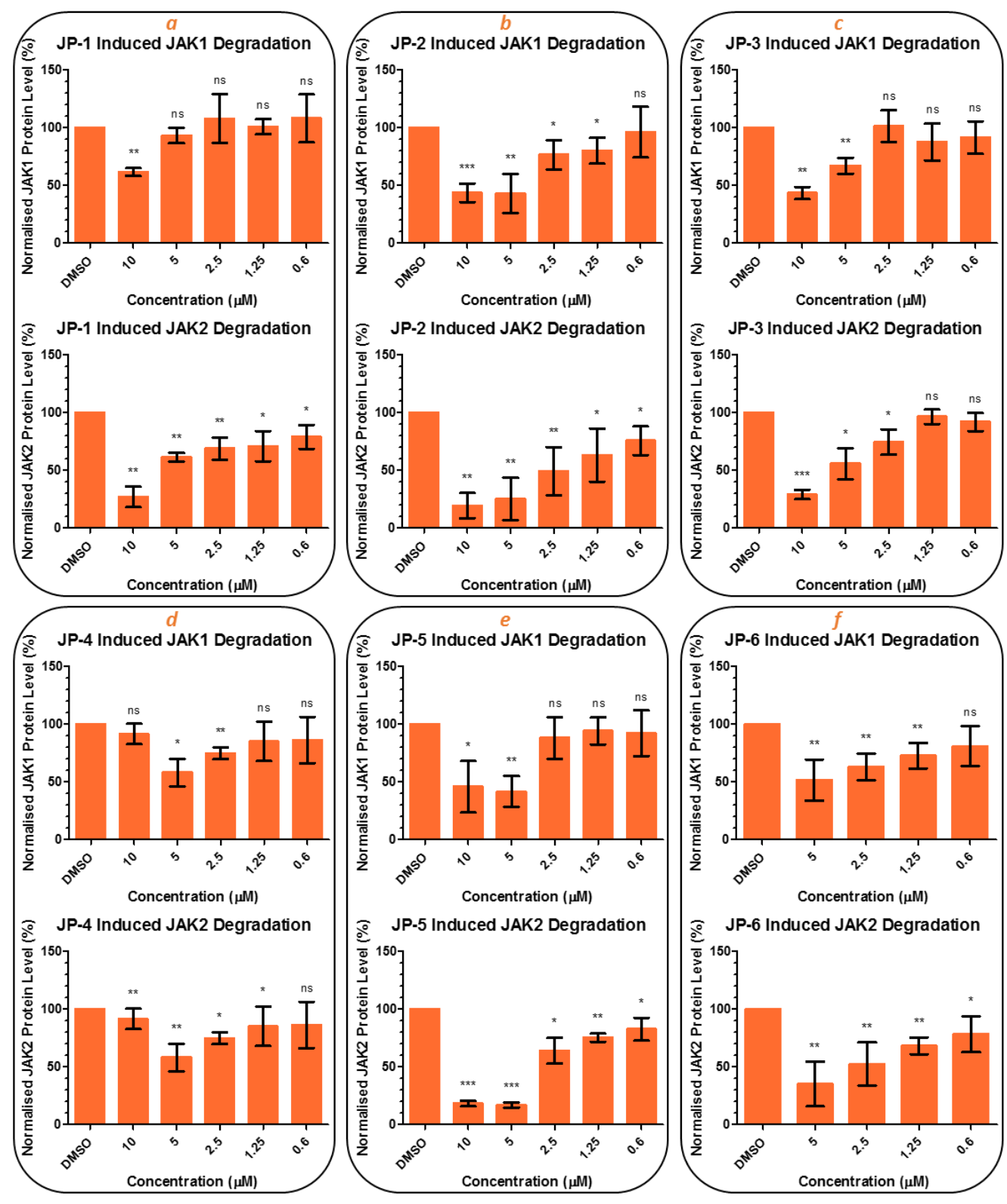

Figure 3 Quantification of JAK1 and JAK2 degradation by PROTACS JP1 - JP6. THP-1 cells were treated with a range of concentrations of PROTACs $(0.6-10 \mu \mathrm{M})$. Following a $24 \mathrm{~h}$ incubation period, the levels of JAK1/JAK2 degradation was determined by automated Western blot analysis. \% Degradation are quoted as a mean of multiple, separate experiments ( $\mathrm{n}$ $\geq 3$ ). One-tailed, student's t-test was performed to assess the significance of JAK1 or JAK2 degradation at individual PROTAC concentrations when compared to the basal JAK1 or JAK2 levels in DMSO treated cells, ${ }^{* * *}=\mathrm{P}<0.001 ;{ }^{* *}=\mathrm{P}<0.01 ;^{*}=\mathrm{P}$ $<0.05 ; \mathrm{ns}=$ non-significant. Individual western blot visualisations are displayed in Figure S3 - S8.

Whilst no beneficial downstream biological response through IFNy signalling inhibition was observed between the JAK warheads and the JAK PROTACs within the IL-2 PBMC assay, a prolonged incubation of the PROTACs within the IL-2 PBMC assay beyond the $1 \mathrm{~h}$ incubation period may result in improved cell potency. Additionally, further characterisation within a JAK2-dependent cellular assay may highlight enhanced biological activity. Furthermore, optimisation of the linker could result in enhanced JAK degraders, however, such efforts remained outside the scope of this proof of concept study.

2.5 Implications of Physicochemical Properties on Degradation Efficiency. Within our immunoblotting assays, each PROTAC was tested across a wide range of concentrations $(0.6-10 \mu \mathrm{M})$ 
per condition to comprehend the impact of subtle differences of the linker, ligation vector and physicochemical properties between the PROTACs on degradation efficiency.

In relation to HBD count, the most efficient degraders of our library, JP-1 - JP-6, all possessed a HBD count within our targeted physicochemical space for enhanced cell penetration; HBD count $\leq 6$ ( $1 \mathrm{HBD}$ was concealed via an intramolecular HBD if the count was greater than 5). However, the ChromLog $\mathrm{D}_{7.4}$ values resided within the upper range and exceeded our initial ChromLogD $D_{7.4}$ guideline of $4-6$. As such, the initial ChromLogD $D_{7.4}$ guidelines were deemed suboptimal for cell penetrant JAK PROTACs, and thus were re-evaluated and adjusted. Our data set suggested a ChromLogD $D_{7.4}$ range of $5-8$ for cell penetrant JAK PROTACs (Figure S17). Perhaps unsurprisingly, JP-1 - JP-6 possessed some of the smallest drop-off in potency values from the JAK1 and JAK3 biochemical assays to the cell (Figure 2). Interestingly, JP-4 was the only PROTAC of the set to exhibit the 'hook effect' at $10 \mu \mathrm{M}$ at both JAK1 and JAK2. ${ }^{39}$ Even though JAK1/2 expression has been normalised to corresponding $\beta$-actin expression in each case, we cannot completely exclude the possibility that the perceived 'hook effect' could be an artefact of the unequal total protein loading seen at $10 \mu \mathrm{M}$ concentration of the compound.

2.6 Mechanism of Action. To confirm JAK degradation was IAP-dependent, we synthesised negative control JP-6-Inverse, whereby all stereocenters within the IAP moiety had been inverted, thus rendering the PROTAC unable to bind IAP and form the ternary complex required for ubiquitination to occur (Table S8). The inverted IAP analog was confirmed to be unable to bind IAP within biochemical IAP assays (BIR2 XIAP pIC $50<4$, BIR3 XIAP $\mathrm{plC}_{50}<4$, BIR3 cIAP plC $_{50}<4$ ). At the highest concentration tested $(5 \mu \mathrm{M})$, where the analogous active PROTAC, JP-6, could induce JAK1 degradation by $48 \%$ and JAK2 degradation by $65 \%$, JP-6-Inverse did not significantly decrease JAK1 or JAK2 protein levels (Figure 4a; Figure 4b; individual western blot visualisations: Figure S9 - S10), thus, indicating IAPdependent JAK degradation. Additionally, co-treatment of THP-1 cells with JP-6, and increasing concentrations of the free, active IAP ligand dose-dependently ameliorated the ability of JP-6 to reduce JAK1 and JAK2 protein levels (Figure 4a; Figure 4b; individual western blot visualisations: Figure S11 - S12), conclusively demonstrating the IAP-dependent nature of PROTAC-mediated JAK degradation.

The requirement for the JAK PROTACs to facilitate ternary complex formation between JAK and IAP, to induce JAK degradation, was also investigated. Treatment of THP-1 cells with Quinoxaline-2, (the parent JAK ligand of JP-6), either alone or in combination with the free IAP ligand, had no marked effect on JAK1 or JAK2 protein levels (Figure 4c; Figure 4d; individual western blot visualisations: Figures S13 - S14). This highlights the necessity of ternary complex formation, to induce JAK degradation. Moreover, the inability of Quinoxaline-2 to impact JAK1 or JAK2 protein levels contrasts previous reports indicating that JAK inhibitors may cause a downregulation of JAK2 expression. ${ }^{2}$ 

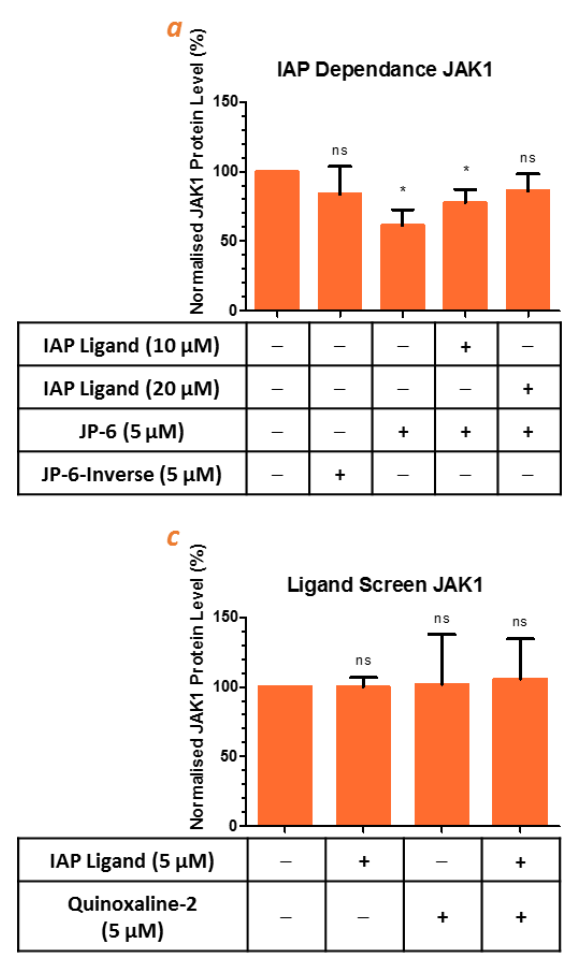
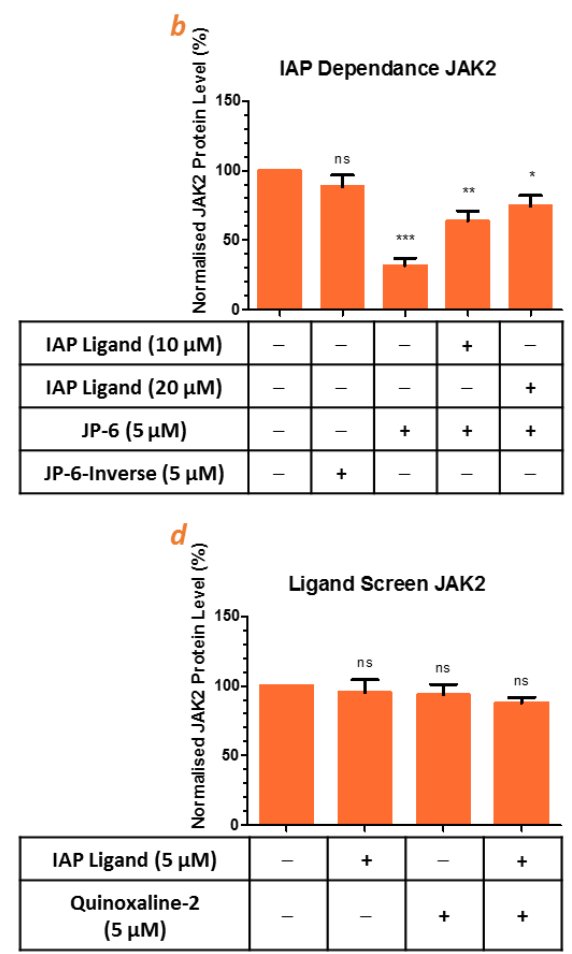

Figure 4 IAP dependence of PROTAC activity. a) and b) JAK1 and JAK2 protein levels determined by automated Western blot analysis of JP-6-Inverse, which failed to illicit JAK degradation. Competition between JP-6 with increasing free IAP ligand restores basal JAK protein levels at JAK1 and JAK2. Degradation values are quoted as a mean of multiple, separate experiments $(n=\geq 3$ ). One-tailed, student's t-test was performed to assess the significance of JAK1 or JAK2 degradation at individual PROTAC concentrations when compared to the basal JAK1 or JAK2 levels in DMSO treated cells, $* * *=\mathrm{P}<0.001$; $*^{* *}=\mathrm{P}<0.01 ;{ }^{*}=\mathrm{P}<0.05 ; \mathrm{ns}=$ non-significant. Individual western blot visualisations are displayed in Figure S9 $-\mathrm{S} 12$.

The ubiquitination state of JAK2 in response to JAK PROTAC exposure was next investigated through immunoprecipitation experiments. The proteasome inhibitor, MG132, was employed to facilitate the accumulation of ubiquitinated JAK, and enable its visualisation by immunoblotting. Treatment with JP-6 induced a greater extent of JAK2 ubiquitination compared to DMSO treatment, confirming the ubiquitin-mediated, and proteasome-dependent mechanism of PROTAC-induced JAK2 degradation (Figure S18). Proteasome dependence of PROTAC-mediated JAK1 and JAK2 degradation was further elucidated through co-treatment experiments with JP-6 and MG132 within THP-1 cells. Co-treatment with MG132 resulted in complete abrogation of PROTAC-mediated JAK1 and JAK2 degradation (Figure S19; individual western blot visualisations: Figures S15 - S16).

In conclusion, degradation of JAK1 and JAK2 was achieved across both JAK chemotypes and all explored vectors, documenting the first PROTACs capable of degrading JAK and proximal membranebound proteins, thus advancing PROTAC technology.

A comparison of JP-6 and JP-6-Inverse within our Western blot assay determined PROTAC-mediated JAK degradation to be IAP-dependent. The IAP dependent nature of JP-1 - JP-6 mediated JAK degradation was further confirmed via significant reduction of degradation in the presence of a competitive small molecule IAP inhibitor. In addition, it was confirmed that JAK degradation was proteasome-dependent through co-treatments of JP-6 and MG132. Accumulation of ubiquitinated JAK2 was observed when cells were co-treated with JP-6 and MG132, illustrating enhanced ubiquitination of JAK2 in the presence of JP-6. 
A physicochemical space encompassing and exceeding our initial target space was explored. JP-1 - JP6 possessed the greatest degradation efficiency and displayed minor drop-off values from the biochemical assays to the cell. The physicochemical properties of these active PROTACs, along with data derived from our PROTAC library suggests hypothesised ChromLogD $D_{7.4}$ guidelines of $5-8$ for cell penetrant JAK PROTACs. Adopting such guidelines in the design of PROTACs targeting proximal membrane-bound proteins, in combination with a HBD count of $\leq 6$ (if one or more HBDs are masked via an intramolecular HB), may result in PROTACs with enhanced cellular permeation. However, optimisation focused exclusively on increasing cell permeation may negatively impact on other DMPK parameters.

\section{Experimental}

The following section contains experimental detail relating to the final compounds within this paper. A description of all cell cultures, Western assays, and experimental procedures for the synthesis of intermediates are available in the Supporting Information.

\section{(2S,4S)-4-(14-(4-((5-Chloro-4-((2,5-difluorobenzyl)amino)pyrimidin-2-yl)amino)-1H-pyrazol-1-yl)- 3,6,9,12-tetraoxatetradecanamido)-1-((S)-2-cyclohexyl-2-((S)-2-(methylamino)propanamido)- acetyl)-N-((R)-1,2,3,4-tetrahydronaphthalen-1-yl)pyrrolidine-2-carboxamide (JP-1, 6)}

14-(4-((5-Chloro-4-((2,5-difluorobenzyl)amino)pyrimidin-2-yl)amino)-1H-pyrazol-1-yl)-3,6,9,12tetraoxatetradecanoic acid $(122 \mathrm{mg}, 0.175 \mathrm{mmol})$, tert-butyl $((S)-1-(((S)-2-((2 S, 4 S)-4$-amino-2-(((R)1,2,3,4-tetrahydronaphthalen-1-yl)carbamoyl)pyrrolidin-1-yl)-1-cyclohexyl-2-oxoethyl)amino)-1oxopropan-2-yl)(methyl)carbamate (123 mg, $0.210 \mathrm{mmol})$, triethylamine $(73.3 \mu \mathrm{L}, 0.526 \mathrm{mmol}$ ) and HATU (100 mg, $0.263 \mathrm{mmol}$ ) were stirred together in DMF $(3.50 \mathrm{~mL})$ for $15 \mathrm{~h}$ at room temperature. The reaction mixture was diluted with water $(10 \mathrm{~mL})$ and extracted with DCM $(3 \times 10 \mathrm{~mL})$. The organic layers were combined, passed through a hydrophobic frit and the solvent was concentrated in vacuo. TFA ( $135 \mu \mathrm{L}, 1.752 \mathrm{mmol}$ ) was added and the reaction mixture was stirred at room temperature for $16 \mathrm{~h}$. The reaction mixture was purified directly by MDAP (ammonium carbonate modifier). The solvent was removed in vacuo to afford (2S,4S)-4-(14-(4-((5-chloro-4-((2,5-difluorobenzyl)amino)pyrimidin-2-yl)amino)-1H-pyrazol-1-yl)-3,6,9,12-tetraoxatetra-decanamido)-1-((S)-2-

cyclohexyl-2-((S)-2-(methylamino)propanamido)-acetyl)- $N$-((R)-1,2,3,4-tetra-hydronaphthalen-1-

yl)pyrrolidine-2-carboxamide (JP-1) $(65 \mathrm{mg}, 0.063 \mathrm{mmol}, 36 \%$ yield) as a white solid. M.pt.: $90-92$ ${ }^{\circ} \mathrm{C} ; v_{\max }$ (neat): $3263,3061,2927,2855,1608,1574,1490 \mathrm{~cm}^{-1} ;{ }^{1} \mathrm{H}$ NMR $\left(400 \mathrm{MHz}\right.$, DMSO- $\left.d_{6}\right) \delta=9.03$ $(1 \mathrm{H}, \mathrm{br} \mathrm{s}), 8.44(1 \mathrm{H}, \mathrm{d}, J=8.8 \mathrm{~Hz}), 8.32(1 \mathrm{H}, \mathrm{br} \mathrm{d}, J=8.6 \mathrm{~Hz}), 8.28(1 \mathrm{H}, \mathrm{s}), 8.09(1 \mathrm{H}, \mathrm{d}, J=8.3 \mathrm{~Hz}), 7.94$ $(1 \mathrm{H}, \mathrm{s}), 7.60-7.70(1 \mathrm{H}, \mathrm{m}), 7.22-7.38(3 \mathrm{H}, \mathrm{m}), 7.01-7.17(5 \mathrm{H}, \mathrm{m}), 4.90-5.00(2 \mathrm{H}, \mathrm{m}), 4.66(2 \mathrm{H}, \mathrm{br} d$, $J=5.9 \mathrm{~Hz}), 4.33-4.49(3 \mathrm{H}, \mathrm{m}), 3.99-4.12(3 \mathrm{H}, \mathrm{m}), 3.88(2 \mathrm{H}, \mathrm{s}), 3.66(2 \mathrm{H}, \mathrm{brt}, J=5.4 \mathrm{~Hz}), 3.43-3.59$ $(12 \mathrm{H}, \mathrm{m}), 2.65-2.79(2 \mathrm{H}, \mathrm{m}), 2.34-2.43(1 \mathrm{H}, \mathrm{m}), 2.20-2.29(3 \mathrm{H}, \mathrm{m}), 2.07(2 \mathrm{H}, \mathrm{s}), 1.77-1.89(4 \mathrm{H}, \mathrm{m})$, 1.55 - $1.77(7 \mathrm{H}, \mathrm{m}), 0.93-1.21(8 \mathrm{H}, \mathrm{m}) ;{ }^{13} \mathrm{C}$ NMR $\left(101 \mathrm{MHz}, \mathrm{DMSO}-d_{6}\right) \delta=172.0,169.9,168.7,167.9$, $163.1,156.5,157.1$ (d, J = 239.9 Hz), 154.8 (d, J = 239.9 Hz), 152.4, 136.2, 135.8, 128.7 (2C), 127.3 (dd, $J=16.1,4.4 \mathrm{~Hz}$ ), $125.5(2 \mathrm{C}), 124.5(2 \mathrm{C}), 122.1,118.4,115.5$ (dd, $J=24.2,8.8 \mathrm{~Hz}), 113.7$ (dd, J = 24.6, $8.4 \mathrm{~Hz}), 69.3,68.8,68.6,68.6,68.5,68.5,68.4,68.1,57.4,57.2,56.8,53.4,51.8,50.2,46.3,45.6,36.3$, $33.1,32.3,32.1,28.6,27.6,26.9,24.7,24.6,24.4,19.1,17.2,17.0 ;{ }^{19} \mathrm{~F}$ NMR $\left(376 \mathrm{MHz}\right.$, DMSO-d $\left.d_{6}\right) \delta=-$ $118.66(\mathrm{~s}),-124.35(\mathrm{~s}) ;$ LCMS (Method B): $\mathrm{t}_{\mathrm{R}}=1.22 \mathrm{~min},[(\mathrm{M}+2 \mathrm{H}) / 2]^{+} 519$ (99\% purity); HRMS: $\left(\mathrm{C}_{51} \mathrm{H}_{70} \mathrm{ClF}_{2} \mathrm{~N}_{11} \mathrm{O}_{8}\right)[(\mathrm{M}+2 \mathrm{H}) / 2]^{+}$requires 518.7532 , found $[(\mathrm{M}+2 \mathrm{H}) / 2]^{+} 518.7541$. 
(2S,4S)-4-(10-(4-((5-Chloro-4-((2,5-difluorobenzyl)amino)pyrimidin-2-yl)amino)-1H-pyrazol-1yl)decanamido)-1-((S)-2-cyclohexyl-2-((S)-2-(methylamino)propanamido)acetyl)-N-((R)-1,2,3,4tetrahydronaphthalen-1-yl)pyrrolidine-2-carboxamide (JP-2, 7)

10-(4-((5-Chloro-4-((2,5-difluorobenzyl)amino)pyrimidin-2-yl)amino)-1H-pyrazol-1-yl)decanoic acid (141 mg, $0.278 \quad \mathrm{mmol}), \quad$ tert-butyl $((S)-1-(((S)-2-((2 S, 4 S)-4$-amino-2-(((R)-1,2,3,4-tetrahydronaphthalen-1-yl)carbamoyl)pyrrolidin-1-yl)-1-cyclohexyl-2-oxoethyl)amino)-1-oxopropan-2-

$\mathrm{yl})$ (methyl)carbamate (195 mg, $0.334 \mathrm{mmol})$, triethylamine $(116 \mu \mathrm{L}, 0.834 \mathrm{mmol})$ and HATU (159 mg, $0.417 \mathrm{mmol}$ ) were stirred together in DMF $(5.56 \mathrm{~mL})$ for $16 \mathrm{~h}$ at room temperature. TFA ( $214 \mu \mathrm{L}, 2.78$ $\mathrm{mmol}$ ) was added and the reaction mixture was stirred for a further $16 \mathrm{~h}$. The reaction mixture was concentrated in vacuo purified directly by MDAP (ammonium carbonate modifier). The solvent was removed in vacuo. The residue was purified by reverse phase column chromatography $(50-95 \%$ $\mathrm{MeCN}$ in $\left.\mathrm{H}_{2} \mathrm{O}+0.1 \% \mathrm{NH}_{4} \mathrm{HCO}_{3}, 120 \mathrm{~g} \mathrm{C} 18\right)$ to afford $(25,4 S)-4-(10-(4-((5-$ chloro-4- $((2,5-$ difluorobenzyl)amino)pyrimidin-2-yl)amino)-1H-pyrazol-1-yl)decanamido)-1-((S)-2-cyclohexyl-2-((S)2-(methylamino)propanamido)acetyl)- $N$-((R)-1,2,3,4-tetrahydronaphthalen-1-yl)pyrrolidine-2carboxamide (JP-2) $\left(82 \mathrm{mg}, 0.084 \mathrm{mmol}, 30 \%\right.$ yield) as a white solid. M.pt.: $100-102^{\circ} \mathrm{C} ; v_{\max }$ (neat): $3281,2927,2854,1645,1574,1490 \mathrm{~cm}^{-1} ;{ }^{1} \mathrm{H}$ NMR $\left(400 \mathrm{MHz}\right.$, DMSO-d $\left.d_{6}\right) \delta=9.06(1 \mathrm{H}, \mathrm{br} \mathrm{s}), 8.40(1 \mathrm{H}$, $\mathrm{d}, J=8.6 \mathrm{~Hz}), 8.11(1 \mathrm{H}, \mathrm{d}, J=7.8 \mathrm{~Hz}), 7.94(1 \mathrm{H}, \mathrm{s}), 7.90(1 \mathrm{H}, \mathrm{d}, J=8.6 \mathrm{~Hz}), 7.67(1 \mathrm{H}, \mathrm{br} \mathrm{s}), 7.53(1 \mathrm{H}, \mathrm{br}$ s), $7.22-7.37(3 \mathrm{H}, \mathrm{m}), 7.01-7.19(5 \mathrm{H}, \mathrm{m}), 5.75(1 \mathrm{H}, \mathrm{s}), 4.89-4.98(1 \mathrm{H}, \mathrm{m}), 4.67(2 \mathrm{H}, \mathrm{br} \mathrm{d}, J=5.6 \mathrm{~Hz})$, $4.39(1 \mathrm{H}, \mathrm{brt}, \mathrm{J}=8.1 \mathrm{~Hz}), 4.23-4.34(2 \mathrm{H}, \mathrm{m}), 4.02-4.10(1 \mathrm{H}, \mathrm{m}), 3.90(2 \mathrm{H}, \mathrm{br} \mathrm{s}), 3.33-3.41(1 \mathrm{H}, \mathrm{m})$, $2.96(1 \mathrm{H}, \mathrm{q}, J=6.8 \mathrm{~Hz}), 2.64-2.80(2 \mathrm{H}, \mathrm{m}), 2.33-2.43(1 \mathrm{H}, \mathrm{m}), 2.18(2 \mathrm{H}, \mathrm{s}), 2.05(2 \mathrm{H}, \mathrm{brt}, J=7.5 \mathrm{~Hz})$, $1.79-1.90(3 \mathrm{H}, \mathrm{m}), 1.55-1.78(10 \mathrm{H}, \mathrm{m}), 1.40-1.55(2 \mathrm{H}, \mathrm{m}), 1.22(9 \mathrm{H}, \mathrm{br} \mathrm{s}), 1.12-1.18(4 \mathrm{H}, \mathrm{m}), 1.10$ $(3 \mathrm{H}, \mathrm{m}), 0.85-1.08(3 \mathrm{H}, \mathrm{m}) ;{ }^{13} \mathrm{CNMR}\left(101 \mathrm{MHz}, \mathrm{DMSO}-d_{6}\right) \delta=174.8,172.4,171.4,170.4,158.2,158.1$, $158.7(\mathrm{~d}, J=239.2 \mathrm{~Hz}$ ), $156.4(\mathrm{br} \mathrm{d}, J=239.6 \mathrm{~Hz}), 154.1,137.8,137.4,129.9,129.2$ (d, J = 7.3 Hz), 129.1, 128.9 (d, $J=7.3 \mathrm{~Hz}$ ), 127.1, 126.1, 123.6, 117.0 (dd, $J=24.2,8.8 \mathrm{~Hz}), 115.3$ (dd, $J=24.2,8.8 \mathrm{~Hz}$ ), 59.6, $58.9,55.4,54.7,52.9,51.8,48.2,47.2,38.1$ (2C), 36.0, 34.9, 34.7, $30.4(2 \mathrm{C}), 30.3(2 \mathrm{C}), 29.3(2 \mathrm{C}), 29.2$, $29.2,29.1,29.0,28.4,26.5,26.4,26.2,26.0,25.6,20.7,19.5 ;{ }^{19} \mathrm{~F} \mathrm{NMR}\left(376 \mathrm{MHz}\right.$, DMSO- $\left.d_{6}\right) \delta=-118.56$ (s), $-124.50(\mathrm{~s})$; LCMS (Method $\mathrm{B}): \mathrm{t}_{\mathrm{R}}=1.42 \mathrm{~min},[\mathrm{M}+\mathrm{H}]^{+} 973 \& 975$ (100\% purity); HRMS: $\left(\mathrm{C}_{51} \mathrm{H}_{69} \mathrm{ClF}_{2} \mathrm{~N}_{11} \mathrm{O}_{4}\right)[\mathrm{M}+\mathrm{H}]^{+}$requires 972.5190 , found $[\mathrm{M}+\mathrm{H}]^{+} 972.5232$.

(2S,4S)-4-(14-(3-(((5-Chloro-2-((1-methyl-1H-pyrazol-4-yl)amino)pyrimidin-4-yl)amino)methyl)-2,5difluorophenoxy)-3,6,9,12-tetraoxatetradecanamido)-1-((S)-2-cyclohexyl-2-((S)-2-(methylamino)propanamido)acetyl)- $N$-((R)-1,2,3,4-tetrahydronaphthalen-1-yl)pyrrolidine-2-carboxamide (JP-3, 10)

3-(((5-Chloro-2-((1-methyl-1H-pyrazol-4-yl)amino)pyrimidin-4-yl)amino)methyl)-2,5-difluorophenol $(50 \mathrm{mg}, 0.136 \mathrm{mmol})$ was added to a stirred mixture of tert-butyl ((S)-1-(((S)-2-((2S,4S)-4-(14-chloro3,6,9,12-tetraoxatetradecanamido)-2-(((R)-1,2,3,4-tetrahydronaphthalen-1-yl)carbamoyl)pyrrolidin1-yl)-1-cyclohexyl-2-oxoethyl)amino)-1-oxopropan-2-yl)(methyl)carbamate (114 mg, $0.136 \mathrm{mmol}$ ) and potassium carbonate $(37.7 \mathrm{mg}, 0.273 \mathrm{mmol})$ in DMF $(418 \mu \mathrm{L})$. The reaction mixture was heated to $80^{\circ} \mathrm{C}$ for $16 \mathrm{~h}$ under a nitrogen atmosphere. The reaction mixture was cooled to room temperature and diluted with water $(10 \mathrm{~mL})$ and extracted with $\mathrm{DCM}(3 \times 10 \mathrm{~mL})$. The organic layers were combined, passed through a hydrophobic frit and the solvent was removed in vacuo. TFA (105 $\mu \mathrm{L}, 1.363 \mathrm{mmol}$ ) was added and the reaction mixture was stirred at room temperature for $1 \mathrm{~h}$. The solvent was removed in vacuo and purified by MDAP (ammonium carbonate modifier) to afford $(2 S, 4 S)$-4-(14-(3(((5-chloro-2-((1-methyl-1H-pyrazol-4-yl)amino)pyrimidin-4-yl)amino)methyl)-2,5-difluorophenoxy)- 
3,6,9,12-tetraoxatetradecanamido)-1-((S)-2-cyclohexyl-2-((S)-2-(methylamino)propanamido)acetyl)$\mathrm{N}$-((R)-1,2,3,4-tetrahydronaphthalen-1-yl)pyrrolidine-2-carboxamide (JP-3) $(68 \mathrm{mg}, 0.064 \mathrm{mmol}, 47 \%$ yield) as a white gum. $v_{\max }$ (neat): $3280,2928,2856,1630,1607,1574,1490 \mathrm{~cm}^{-1}$; ${ }^{1} \mathrm{H} \mathrm{NMR}$ (400 MHz, DMSO- $\left.d_{6}\right) \delta=9.04(1 \mathrm{H}, \mathrm{br} \mathrm{s}), 8.45(1 \mathrm{H}, \mathrm{d}, J=8.6 \mathrm{~Hz}), 8.25-8.38(2 \mathrm{H}, \mathrm{m}), 7.90-8.00(2 \mathrm{H}, \mathrm{m}), 7.69(1 \mathrm{H}$, br s), $7.24-7.35(2 \mathrm{H}, \mathrm{m}), 7.05-7.20(4 \mathrm{H}, \mathrm{m}), 7.01(1 \mathrm{H}, \mathrm{ddd}, J=10.0,6.7,3.1 \mathrm{~Hz}), 6.53-6.62(1 \mathrm{H}, \mathrm{m})$, 4.90 - $4.99(1 \mathrm{H}, \mathrm{m}), 4.65(2 \mathrm{H}, \mathrm{br} \mathrm{d}, J=5.9 \mathrm{~Hz}), 4.42-4.49(1 \mathrm{H}, \mathrm{m}), 4.32-4.41(2 \mathrm{H}, \mathrm{m}), 4.14-4.22(2 \mathrm{H}$, m), $4.03(1 \mathrm{H}, \mathrm{dd}, J=10.0,6.4 \mathrm{~Hz}), 3.90(2 \mathrm{H}, \mathrm{s}), 3.73-3.78(3 \mathrm{H}, \mathrm{m}), 3.68-3.73(3 \mathrm{H}, \mathrm{m}), 3.56-3.60(6 \mathrm{H}$, m), $3.47-3.50(3 \mathrm{H}, \mathrm{m}), 3.02(1 \mathrm{H}, \mathrm{q}, J=6.8 \mathrm{~Hz}), 2.67-2.78(2 \mathrm{H}, \mathrm{m}), 2.35-2.44(1 \mathrm{H}, \mathrm{m}), 2.20(3 \mathrm{H}, \mathrm{s})$, 1.62 - $1.88(12 \mathrm{H}, \mathrm{m}), 0.95-1.22(10 \mathrm{H}, \mathrm{m}) ;{ }^{13} \mathrm{C} \mathrm{NMR}\left(101 \mathrm{MHz}\right.$, DMSO- $\left.d_{6}\right) \delta=174.5,171.6,170.4,169.5$, 158.0, $158.4(\mathrm{~d}, J=238.4 \mathrm{~Hz}), 154.0,147.6(\mathrm{t}, J=11.7 \mathrm{~Hz}), 144.9,137.8,137.4,129.9(2 \mathrm{C}), 129.0,128.9$, $127.1,126.1(2 \mathrm{C}), 123.9,105.0,101.6(\mathrm{~d}, J=27.1 \mathrm{~Hz}), 70.9$ (2C), $70.5(2 \mathrm{C}), 70.4,70.3,70.2,70.1,69.3$, 69.2, 59.3, 59.0, 54.8, 53.4, 47.9, 47.2, 38.9 (2C), 38.0, 34.7, 34.4 (3C), 30.2, 29.2, 28.5, 26.4, 26.2, 26.0, 20.7, 19.3; ${ }^{19} \mathrm{~F}$ NMR (376 MHz, DMSO- $d_{6}$ ) $\delta=-116.10(\mathrm{~s}),-145.60$ (s); LCMS (Method B): $\mathrm{t}_{\mathrm{R}}=1.21 \mathrm{~min}$, $[\mathrm{M}+\mathrm{H}]^{+} 1067$ \& 1069 (99 \% purity); HRMS: $\left(\mathrm{C}_{52} \mathrm{H}_{72} \mathrm{ClF}_{2} \mathrm{~N}_{11} \mathrm{O}_{9}\right) \quad[(\mathrm{M}+2 \mathrm{H}) / 2]^{+}$requires 533.7586 , found $[(\mathrm{M}+2 \mathrm{H}) / 2]^{+} 533.7592$.

(2S,4S)-4-(10-(3-(((5-Chloro-2-((1-methyl-1H-pyrazol-4-yl)amino)pyrimidin-4-yl)amino)methyl)-2,5difluorophenoxy)decanamido)-1-((S)-2-cyclohexyl-2-((S)-2-(methylamino)propanamido)acetyl)- $N$ ((R)-1,2,3,4-tetrahydronaphthalen-1-yl)pyrrolidine-2-carboxamide (JP-4, 13)

10-(3-(((5-Chloro-2-((1-methyl-1H-pyrazol-4-yl)amino)pyrimidin-4-yl)amino)methyl)-2,5-difluorophenoxy)decanoic acid (100 mg, $0.186 \mathrm{mmol})$, tert-butyl ((S)-1-(((S)-2-((2S,4S)-4-amino-2-(((R)-1,2,3,4tetrahydronaphthalen-1-yl)carbamoyl)pyrrolidin-1-yl)-1-cyclohexyl-2-oxoethyl)amino)-1-oxopropan2-yl)(methyl)carbamate (130 mg, $0.223 \mathrm{mmol})$, triethylamine $(78 \mu \mathrm{L}, 0.559 \mathrm{mmol})$ and HATU (106 mg, $0.279 \mathrm{mmol})$ were stirred together in DMF $(3.72 \mathrm{~mL})$ for $16 \mathrm{~h}$ at room temperature. The reaction mixture was diluted with water $(10 \mathrm{~mL})$ and extracted with DCM $(3 \times 10 \mathrm{~mL})$. The solvent was concentrated in vacuo. TFA (143 $\mu \mathrm{L}, 1.862 \mathrm{mmol}$ ) was added and the reaction mixture was stirred at room temperature for $16 \mathrm{~h}$. The reaction mixture was diluted with water $(10 \mathrm{~mL})$ and extracted with DCM $(3 \times 10 \mathrm{~mL})$. The solvent was concentrated in vacuo and purified by reverse phase prep column chromatography ( $40-95 \% \mathrm{MeCN}$ in $\mathrm{H}_{2} \mathrm{O}+0.1 \% \mathrm{NH}_{4} \mathrm{HCO}_{3}$, XBridge $\mathrm{C}_{18}, 42 \mathrm{~mL} / \mathrm{min}, 45 \mathrm{~min}$ ) to afford (2S,4S)-4-(10-(3-(((5-chloro-2-((1-methyl-1H-pyrazol-4-yl)amino)pyrimidin-4-yl)amino)-methyl)-2,5difluorophenoxy)decanamido)-1-((S)-2-cyclohexyl-2-((S)-2-(methylamino)propanamido)-acetyl)- $N$ ((R)-1,2,3,4-tetrahydronaphthalen-1-yl)pyrrolidine-2-carboxamide (JP-4) $(100 \mathrm{mg}, 0.100 \mathrm{mmol}, 54 \%$ yield) as a white solid. M.pt.: $103-105^{\circ} \mathrm{C} ; v_{\max }$ (neat): 3296, 2927, 2854, 1634, 1574, 1430, $778 \mathrm{~cm}^{-1}$; ${ }^{1} \mathrm{H}$ NMR $(400 \mathrm{MHz}, \mathrm{MeOD}) \delta=7.83(1 \mathrm{H}, \mathrm{s}), 7.55(1 \mathrm{H}, \mathrm{s}), 7.35-7.40(1 \mathrm{H}, \mathrm{m}), 7.34(1 \mathrm{H}, \mathrm{s}), 7.08$ - 7.15 $(2 \mathrm{H}, \mathrm{m}), 7.01-7.06(1 \mathrm{H}, \mathrm{m}), 6.72(1 \mathrm{H}, \mathrm{ddd}, J=9.9,6.7,2.9 \mathrm{~Hz}), 6.49-6.56(1 \mathrm{H}, \mathrm{m}), 5.02-5.07(1 \mathrm{H}, \mathrm{m})$, $4.71(2 \mathrm{H}, \mathrm{s}), 4.42-4.55(3 \mathrm{H}, \mathrm{m}), 4.12-4.20(1 \mathrm{H}, \mathrm{m}), 3.97(2 \mathrm{H}, \mathrm{t}, J=6.4 \mathrm{~Hz}), 3.75(3 \mathrm{H}, \mathrm{s}), 3.60(1 \mathrm{H}, \mathrm{dd}$, $J=10.4,5.3 \mathrm{~Hz}), 3.09-3.16(1 \mathrm{H}, \mathrm{m}), 2.67-2.83(2 \mathrm{H}, \mathrm{m}), 2.50(1 \mathrm{H}, \mathrm{ddd}, J=13.2,8.8,6.6 \mathrm{~Hz}), 2.29(2 \mathrm{H}$, s), $2.28(1 \mathrm{H}, \mathrm{s}), 2.19(2 \mathrm{H}, \mathrm{t}, J=7.6 \mathrm{~Hz}), 1.69-2.03(14 \mathrm{H}, \mathrm{m}), 1.57-1.68(4 \mathrm{H}, \mathrm{m}), 1.38-1.55(3 \mathrm{H}, \mathrm{m})$, $1.34(8 \mathrm{H}, \mathrm{s}), 0.99-1.31(10 \mathrm{H}, \mathrm{m}) ;{ }^{13} \mathrm{C}$ NMR $(101 \mathrm{MHz}, \mathrm{MeOD}) \delta=175.8,174.3,172.0,171.3,158.3$, $157.8,158.7$ (dd, $J=241.0,2.6 \mathrm{~Hz}$ ), 152.8, 147.8 (dd, $J=11.7,10.3 \mathrm{~Hz}), 146.2$ (dd, $J=238.4,2.2 \mathrm{~Hz}$ ), 137.1, 136.1, 129.9, 128.5, 128.4, 128.3, 128.2, 128.2, 126.7, 125.7, 123.6, 121.1, 104.3 (dd, J = 24.9, $2.2 \mathrm{~Hz}$ ), 103.2, 100.5 (d, J = 27.9 Hz), 69.2, 59.4, 58.9, 55.5, 53.2, 48.6, 47.8, 40.1, 37.6, 36.0, 34.2, 33.5 (dd, J = 6.6, 2.2 Hz), 33.2, 29.8, 29.2, 29.1, 29.0, 28.9, 28.9, 28.8, 28.6, 28.5, 25.9, 25.7, 25.5, 20.2, 17.9; LCMS (Method B): $\mathrm{t}_{\mathrm{R}}=1.49 \mathrm{~min},[\mathrm{M}+\mathrm{H}]^{+} 1003 \& 1005$ (100\% purity); HRMS: $\left(\mathrm{C}_{52} \mathrm{H}_{71} \mathrm{ClF}_{2} \mathrm{~N}_{11} \mathrm{O}_{5}\right)[\mathrm{M}+\mathrm{H}]^{+}$ requires 1002.5296 , found $[\mathrm{M}+\mathrm{H}]^{+} 1002.5303$. 
(2S,4S)-1-((S)-2-Cyclohexyl-2-((S)-2-(methylamino)propanamido)acetyl)-4-(14-(4-(3-(4-(8-(4-((1,1dioxidothiomorpholino)methyl)-3,5-difluorophenyl)quinoxalin-2-yl)-2-methoxyphenoxy)propyl)piperazin-1-yl)-3,6,9,12-tetraoxatetradecanamido)- $N$-((R)-1,2,3,4-tetrahydronaphthalen-1-yl)pyrrolidine-2-carboxamide (JP-5, 15)

4-(2,6-Difluoro-4-(3-(3-methoxy-4-(3-(piperazin-1-yl)propoxy)phenyl)quinoxalin-5-yl)benzyl)thiomorpholine 1,1-dioxide ( $80 \mathrm{mg}, 0.125 \mathrm{mmol})$ was added to a stirred mixture of tert-butyl ((S)-1-(((S)2-((2S,4S)-4-(14-chloro-3,6,9,12-tetraoxatetradecanamido)-2-(((R)-1,2,3,4-tetrahydronaphthalen-1yl)carbamoyl)pyrrolidin-1-yl)-1-cyclohexyl-2-oxoethyl)amino)-1-oxopropan-2-yl)(methyl)carbamate (126 mg, $0.151 \mathrm{mmol}$ ), sodium iodide $(23 \mathrm{mg}, 0.153 \mathrm{mmol}$ ) and potassium carbonate ( $35 \mathrm{mg}, 0.253$ $\mathrm{mmol})$ in DMF $(385 \mu \mathrm{L})$. The reaction mixture was heated to $100{ }^{\circ} \mathrm{C}$ for $1 \mathrm{~h}$ under a nitrogen atmosphere. The reaction mixture was cooled to room temperature and diluted with water $(10 \mathrm{~mL})$ and extracted with DCM $(3 \times 10 \mathrm{~mL})$. The organic layers were combined, passed through a hydrophobic frit and the solvent was concentrated in vacuo. TFA ( $97 \mu \mathrm{L}, 1.254 \mathrm{mmol}$ ) was added and the reaction mixture was stirred for $16 \mathrm{~h}$ at room temperature. The reaction mixture was diluted with water (10 $\mathrm{mL})$ and extracted with DCM $(3 \times 10 \mathrm{~mL})$. The organic layers were combined, passed through a hydrophobic frit and the solvent was concentrated in vacuo. The residue was purified by reverse phase prep column chromatography ( $30-95 \% \mathrm{MeCN}$ in $\mathrm{H}_{2} \mathrm{O}+0.1 \% \mathrm{NH}_{4} \mathrm{HCO}_{3}$, XBridge $\mathrm{C}_{18}, 42 \mathrm{~mL} / \mathrm{min}, 45$ $\mathrm{min})$ to afford (2S,4S)-1-((S)-2-cyclohexyl-2-((S)-2-(methylamino)propanamido)acetyl)-4-(14-(4-(3-(4(8-(4-((1,1-dioxidothiomorpholino)methyl)-3,5-difluorophenyl)quinoxalin-2-yl)-2-methoxyphenoxy)propyl)piperazin-1-yl)-3,6,9,12-tetraoxatetradecanamido)- $N$-((R)-1,2,3,4-tetrahydronaphthalen-1yl)pyrrolidine-2-carboxamide (127 mg, $0.095 \mathrm{mmol}, 76 \%$ yield) as an orange solid. M.pt.: $69-71{ }^{\circ} \mathrm{C}$; $v_{\max }$ (neat): 3319, 2928, 2851, 1634, 1517, 1429, $1124 \mathrm{~cm}^{-1} ;{ }^{1} \mathrm{H}$ NMR $\left(400 \mathrm{MHz}, \mathrm{CDCl}_{3}\right) \delta=9.38(1 \mathrm{H}, \mathrm{s})$, $8.53(1 \mathrm{H}, \mathrm{d}, J=7.1 \mathrm{~Hz}), 8.15(1 \mathrm{H}, \mathrm{dd}, J=8.2,1.6 \mathrm{~Hz}), 7.88(1 \mathrm{H}, \mathrm{d}, J=2.2 \mathrm{~Hz}), 7.84(1 \mathrm{H}, \mathrm{dd}, J=7.3,1.7$ $\mathrm{Hz}), 7.75-7.80(1 \mathrm{H}, \mathrm{m}), 7.71(1 \mathrm{H}, \mathrm{dd}, J=8.4,2.1 \mathrm{~Hz}), 7.63(1 \mathrm{H}, \mathrm{d}, J=8.3 \mathrm{~Hz}), 7.47-7.55(3 \mathrm{H}, \mathrm{m}), 7.10$ - $7.16(2 \mathrm{H}, \mathrm{m}), 7.00-7.08(3 \mathrm{H}, \mathrm{m}), 5.07-5.16(1 \mathrm{H}, \mathrm{m}), 4.72-4.77(1 \mathrm{H}, \mathrm{m}), 4.64(1 \mathrm{H}, \mathrm{q}, J=6.6 \mathrm{~Hz}), 4.37$ $(1 \mathrm{H}, \mathrm{t}, J=8.2 \mathrm{~Hz}), 4.13-4.21(3 \mathrm{H}, \mathrm{m}), 4.05(2 \mathrm{H}, \mathrm{s}), 3.95(3 \mathrm{H}, \mathrm{s}), 3.93(2 \mathrm{H}, \mathrm{s}), 3.67-3.74(4 \mathrm{H}, \mathrm{m}), 3.56-$ $3.66(12 \mathrm{H}, \mathrm{m}), 3.06-3.16(8 \mathrm{H}, \mathrm{m}), 3.01(1 \mathrm{H}, \mathrm{q}, J=7.0 \mathrm{~Hz}), 2.65-2.85(3 \mathrm{H}, \mathrm{m}), 2.45-2.62(12 \mathrm{H}, \mathrm{m})$, $2.35(3 \mathrm{H}, \mathrm{s}), 2.21(1 \mathrm{H}, \mathrm{ddd}, J=13.6,8.9,6.6 \mathrm{~Hz}), 1.97-2.11(4 \mathrm{H}, \mathrm{m}), 1.76-1.90(4 \mathrm{H}, \mathrm{m}), 1.47-1.62$ $(4 \mathrm{H}, \mathrm{m}), 1.27(3 \mathrm{H}, \mathrm{d}, J=6.8 \mathrm{~Hz}), 1.03-1.14(3 \mathrm{H}, \mathrm{m}), 0.86-1.03(2 \mathrm{H}, \mathrm{m}) ;{ }^{13} \mathrm{C} \mathrm{NMR}\left(101 \mathrm{MHz}, \mathrm{CDCl}_{3}\right) \delta=$ 174.9, 173.1, 170.6, 170.1, 161.3 (2C, dd, $J=246.9,9.2 \mathrm{~Hz}$ ), 151.0, 150.5, 150.2, 142.7, 141.5, 140.7 (t, $J=10.6 \mathrm{~Hz}), 139.4,137.3(\mathrm{t}, J=2.2 \mathrm{~Hz}), 137.2,136.4,130.5,129.9,129.1,129.1,128.8,128.3,127.2$, $126.1,120.2,114.0(2 \mathrm{C}, \mathrm{dd}, J=20.5,7.3 \mathrm{~Hz}), 112.7,110.8(\mathrm{t}, J=20.2 \mathrm{~Hz}), 110.4,71.3,70.9,70.7,70.6$, 70.5, 70.5, 70.3, 68.9, 67.5, 60.3, 60.0, 57.8, 55.7, 55.5, 54.9, 54.7, 53.6 (2C), 53.1 (2C), 51.5 (2C), 50.1 (2C), 48.9, 48.0, 47.7, 40.5, 35.1, 31.1, 30.1, 29.4, 29.2, 28.5, 26.6, 26.0, 26.0, 25.8, 20.2, 19.5; ${ }^{19} \mathrm{~F} \mathrm{NMR}$ $\left(376 \mathrm{MHz}, \mathrm{CDCl}_{3}\right) \delta=-115.2$ (s); LCMS (Method B): $\mathrm{t}_{\mathrm{R}}=1.37 \mathrm{~min},[(\mathrm{M}+2 \mathrm{H}) / 2]^{+} 670$ (100\% purity); HRMS: $\left(\mathrm{C}_{70} \mathrm{H}_{94} \mathrm{~F}_{2} \mathrm{~N}_{10} \mathrm{O}_{12} \mathrm{~S}\right)[(\mathrm{M}+2 \mathrm{H}) / 2]^{+}$requires 669.3449 , found $[(\mathrm{M}+2 \mathrm{H}) / 2]^{+} 669.3454$.

(2S,4S)-1-((S)-2-Cyclohexyl-2-((S)-2-(methylamino)propanamido)acetyl)-4-(10-(4-(3-(4-(8-(4-)(1,1dioxidothiomorpholino)methyl)-3,5-difluorophenyl)quinoxalin-2-yl)-2-methoxyphenoxy)propyl)piperazin-1-yl)decanamido)- $N-((R)-1,2,3,4$-tetrahydronaphthalen-1-yl)pyrrolidine-2-carboxamide (JP-6, 17)

4-(2,6-Difluoro-4-(3-(3-methoxy-4-(3-(piperazin-1-yl)propoxy)phenyl)quinoxalin-5-yl)benzyl)thiomorpholine 1,1-dioxide $(400 \mathrm{mg}, 0.627 \mathrm{mmol}$ ) was added to a stirred mixture of methyl 10 bromodecanoate ( $200 \mathrm{mg}, 0.753 \mathrm{mmol}$ ) and potassium carbonate (173 $\mathrm{mg}, 1.254 \mathrm{mmol}$ ) in DMF (1.92 
$\mathrm{mL}$ ). The reaction mixture was heated to $100{ }^{\circ} \mathrm{C}$ for $16 \mathrm{~h}$ under a nitrogen atmosphere. The reaction mixture was cooled to room temperature and diluted with water $(10 \mathrm{~mL})$ and extracted with DCM (3 $x 10 \mathrm{~mL}$ ). The organic layers were combined, passed through a hydrophobic frit and the solvent was concentrated in vacuo. $\mathrm{LiOH}$ ( $150 \mathrm{mg}, 6.27 \mathrm{mmol}$ ) was added and the reaction mixture was heated at $50{ }^{\circ} \mathrm{C}$ for $3 \mathrm{~h}$ under a nitrogen atmosphere. The reaction mixture was filtered and purified by reverse phase prep column chromatography $\left(30-95 \% \mathrm{MeCN}+0.1 \% \mathrm{HCO}_{2} \mathrm{H}\right.$ in $\mathrm{H}_{2} \mathrm{O}+0.1 \% \mathrm{HCO}_{2} \mathrm{H}$, SunFire $\left.\mathrm{C}_{18}, 42 \mathrm{~mL} / \mathrm{min}, 45 \mathrm{~min}\right)$ to afford 10-(4-(3-(4-(8-(4-((1,1-dioxidothiomorpholino)methyl)-3,5difluorophenyl)quinoxalin-2-yl)-2-methoxyphenoxy)propyl)piperazin-1-yl)decanoic acid (354 mg, $0.438 \mathrm{mmol}, 70 \%$ yield) as a yellow solid. 10-(4-(3-(4-(8-(4-((1,1-Dioxidothiomorpholino)methyl)-3,5difluorophenyl)quinoxalin-2-yl)-2-methoxyphenoxy)propyl)piperazin-1-yl)decanoic acid $(100 \mathrm{mg}$, $0.124 \mathrm{mmol})$, tert-butyl $((S)-1-(((S)-2-((2 S, 4 S)-4$-amino-2- $(((R)-1,2,3,4$-tetrahydronaphthalen-1yl)carbamoyl)pyrrolidin-1-yl)-1-cyclohexyl-2-oxoethyl)amino)-1-oxopropan-2-yl)(methyl)carbamate $(87 \mathrm{mg}, 0.149 \mathrm{mmol})$, triethylamine $(51.8 \mu \mathrm{L}, 0.371 \mathrm{mmol})$ and HATU $(70.6 \mathrm{mg}, 0.186 \mathrm{mmol})$ were stirred together in DMF $(2.475 \mathrm{~mL})$ for $15 \mathrm{~h}$ at room temperature. The reaction mixture was diluted with water $(10 \mathrm{~mL})$ and extracted with DCM $(3 \times 10 \mathrm{~mL})$. The solvent was concentrated in vacuo and TFA (95 $\mu \mathrm{L}, 1.238 \mathrm{mmol}$ ) was added and the reaction mixture was stirred at room temperature for 16 h. The reaction mixture was diluted with water $(10 \mathrm{~mL})$ and extracted with DCM $(3 \times 10 \mathrm{~mL})$. The solvent was concentrated in vacuo and purified by reverse phase prep column chromatography (70$95 \% \mathrm{MeCN}$ in $\mathrm{H}_{2} \mathrm{O}+0.1 \% \mathrm{NH}_{4} \mathrm{HCO}_{3}$, XBridge $\left.\mathrm{C}_{18}, 42 \mathrm{~mL} / \mathrm{min}, 45 \mathrm{~min}\right)$ to afford $(2 \mathrm{~S}, 4 S)-1-((S)-2-$ cyclohexyl-2-((S)-2-(methylamino)propanamido)acetyl)-4-(10-(4-(3-(4-(8-(4-((1,1-dioxidothiomorpholino)methyl)-3,5-difluorophenyl)quinoxalin-2-yl)-2-methoxyphenoxy)propyl)piperazin-1yl)decanamido)- $N$-((R)-1,2,3,4-tetrahydronaphthalen-1-yl)pyrrolidine-2-carboxamide (JP-6) (85 mg, $0.067 \mathrm{mmol}, 54 \%$ yield) as a yellow solid. M.pt.: $100-102{ }^{\circ} \mathrm{C}$; $v_{\max }$ (neat): 3315, 2928, 2853, 1632, 1469, $1126 \mathrm{~cm}^{-1} ;{ }^{1} \mathrm{H}$ NMR $\left(400 \mathrm{MHz}, \mathrm{CDCl}_{3}\right) \delta=9.38(1 \mathrm{H}, \mathrm{s}), 8.14(1 \mathrm{H}, \mathrm{dd}, J=8.2,1.6 \mathrm{~Hz}), 7.88-8.00$ $(1 \mathrm{H}, \mathrm{m}), 7.85(1 \mathrm{H}, \mathrm{d}, J=1.5 \mathrm{~Hz}), 7.85(1 \mathrm{H}, \mathrm{dd}, J=18.2,1.8 \mathrm{~Hz}), 7.79-7.81(1 \mathrm{H}, \mathrm{m}), 7.75-7.79(1 \mathrm{H}, \mathrm{m})$, $7.70(1 \mathrm{H}, \mathrm{dd}, J=8.4,2.1 \mathrm{~Hz}), 7.49(2 \mathrm{H}, \mathrm{d}, J=9.0 \mathrm{~Hz}), 7.11-7.16(2 \mathrm{H}, \mathrm{m}), 7.05-7.09(2 \mathrm{H}, \mathrm{m}), 7.02(1 \mathrm{H}$, $\mathrm{d}, J=8.3 \mathrm{~Hz}), 5.08-5.16(1 \mathrm{H}, \mathrm{m}), 4.74(1 \mathrm{H}, \mathrm{d}, J=8.8 \mathrm{~Hz}), 4.59(1 \mathrm{H}, \mathrm{q}, J=6.1 \mathrm{~Hz}), 4.36(1 \mathrm{H}, \mathrm{t}, J=8.2 \mathrm{~Hz})$, $4.17(2 \mathrm{H}, \mathrm{t}, J=6.7 \mathrm{~Hz}), 4.07(1 \mathrm{H}, \mathrm{dd}, J=11.2,5.1 \mathrm{~Hz}), 3.95(3 \mathrm{H}, \mathrm{s}), 3.93(2 \mathrm{H}, \mathrm{s}), 3.68(1 \mathrm{H}, \mathrm{d}, J=10.8 \mathrm{~Hz})$, $3.07-3.16(8 \mathrm{H}, \mathrm{m}), 3.00-3.04(1 \mathrm{H}, \mathrm{m}), 2.70-2.85(2 \mathrm{H}, \mathrm{m}), 2.47-2.63(9 \mathrm{H}, \mathrm{m}), 2.30-2.43(7 \mathrm{H}, \mathrm{m})$, $1.99-2.24(8 \mathrm{H}, \mathrm{m}), 1.78-1.90(4 \mathrm{H}, \mathrm{m}), 1.67-1.73(2 \mathrm{H}, \mathrm{m}), 1.36-1.63(7 \mathrm{H}, \mathrm{m}), 1.25-1.35(12 \mathrm{H}, \mathrm{m})$, $1.23(1 \mathrm{H}, \mathrm{d}, J=6.8 \mathrm{~Hz}), 1.09(3 \mathrm{H}, \mathrm{br} \mathrm{s}), 0.88-1.05(2 \mathrm{H}, \mathrm{m}) ;{ }^{13} \mathrm{C} \mathrm{NMR}\left(101 \mathrm{MHz}, \mathrm{CDCl}_{3}\right) \delta=175.0,173.3$, $173.1,171.2,161.3(2 \mathrm{C}, \mathrm{dd}, J=246.5,9.5 \mathrm{~Hz}), 150.9,150.5,150.2,142.7,141.4,140.7$ (t, $J=11.0 \mathrm{~Hz})$, 139.4, 137.3, 137.3, 136.1, 130.5, 129.9, 129.2, 129.1, 128.8, 128.2, 127.3, 126.0, 120.1, 114.0 (2C, dd, $J=19.8,5.9 \mathrm{~Hz}), 112.7,110.8(\mathrm{t}, J=20.2 \mathrm{~Hz}), 110.4,67.5,60.2,60.1,60.1,60.0,58.8,55.9,55.7,55.0$, 54.7, $53.2(2 \mathrm{C}), 53.1(2 \mathrm{C}), 51.5(2 \mathrm{C}), 50.1(2 \mathrm{C}), 49.4,48.0,40.6,36.9,35.1,31.1,30.0,29.6,29.4,29.3$, 29.2, 29.1, 28.6, 27.6, 26.8, 26.6, 26.1, 26.0, 25.9, 25.7, 20.1, 19.4; $\left.{ }^{19} \mathrm{~F} \mathrm{NMR} \mathrm{(376} \mathrm{MHz,} \mathrm{CDCl}_{3}\right) \delta=-$ 115.18 (s); LCMS (Method B): $t_{R}=1.62 \mathrm{~min},[(\mathrm{M}+2 \mathrm{H}) / 2]^{+} 637\left(100 \%\right.$ purity); HRMS: $\left(\mathrm{C}_{70} \mathrm{H}_{94} \mathrm{~F}_{2} \mathrm{~N}_{10} \mathrm{O}_{8} \mathrm{~S}\right)$ $[\mathrm{M}+\mathrm{H}]^{+}$requires 1273.7023 , found $[\mathrm{M}+\mathrm{H}]^{+} 1273.7014$.

\section{Acknowledgements}

We thank the GlaxoSmithKline/University of Strathclyde Industrial PhD programme for funding this work. We also thank Chris J. Tame, Markus A. Queisser and John Harling for intellectual discussions, and Neal J. Fazakerley for assistance with data visualisation techniques.

Declarations of interest: none. 


\section{References}

(1) O'Shea, J. J., Schwartz, D. M., Villarino, A. V, Gadina, M., McInnes, I. B., and Laurence, A. (2015) The JAK-STAT Pathway: Impact on Human Disease and Therapeutic Intervention. Annu. Rev. Med. $66,311-328$.

(2) Field, S. D., Arkin, J., Li, J., and Jones, L. H. (2017) Selective Downregulation of JAK2 and JAK3 by an ATP-Competitive pan-JAK Inhibitor. ACS Chem. Biol. 12, 1183-1187.

(3) Zhou, B., Hu, J., Xu, F., Chen, Z., Bai, L., Fernandez-Salas, E., Lin, M., Liu, L., Yang, C.-Y., Zhao, Y., McEachern, D., Przybranowski, S., Wen, B., Sun, D., and Wang, S. (2018) Discovery of a SmallMolecule Degrader of Bromodomain and Extra-Terminal (BET) Proteins with Picomolar Cellular Potencies and Capable of Achieving Tumor Regression. J. Med. Chem. 61, 462-481.

(4) Lu, M., Liu, T., Jiao, Q., Ji, J., Tao, M., Liu, Y., You, Q., and Jiang, Z. (2018) Discovery of a Keap1dependent peptide PROTAC to knockdown Tau by ubiquitination-proteasome degradation pathway. Eur. J. Med. Chem. 146, 251-259.

(5) Burslem, G. M., Smith, B. E., Lai, A. C., Jaime-Figueroa, S., McQuaid, D. C., Bondeson, D. P., Toure, M., Dong, H., Qian, Y., Wang, J., Crew, A. P., Hines, J., and Crews, C. M. (2018) The Advantages of Targeted Protein Degradation Over Inhibition: An RTK Case Study. Cell Chem. Biol. 25, 67-77.e3.

(6) Maniaci, C., Hughes, S. J., Testa, A., Chen, W., Lamont, D. J., Rocha, S., Alessi, D. R., Romeo, R., and Ciulli, A. (2017) Homo-PROTACs: Bivalent small-molecule dimerizers of the VHL E3 ubiquitin ligase to induce self-degradation. Nat. Commun. 8, 1-14.

(7) Rodriguez-Gonzalez, A., Cyrus, K., Salcius, M., Kim, K., Crews, C. M., Deshaies, R. J., and Sakamoto, K. M. (2008) Targeting steroid hormone receptors for ubiquitination and degradation in breast and prostate cancer. Oncogene 27, 7201-7211.

(8) Burslem, G. M., Smith, B. E., Lai, A. C., Jaime-Figueroa, S., McQuaid, D. C., Bondeson, D. P., Toure, M., Dong, H., Qian, Y., Wang, J., Crew, A. P., Hines, J., and Crews, C. M. (2018) The Advantages of Targeted Protein Degradation Over Inhibition: An RTK Case Study. Cell Chem. Biol. 25, 67-77.e3.

(9) Gerspacher, M., Furet, P., Vangrevelinghe, E., Pissot Soldermann, C., Gaul, C., and Holzer, P. (2008) Preparation of quinoxalines, particularly heterocyclyl-substituted diarylquinoxalines, as inhibitors of the tyrosine kinase activity of Janus kinases for use in the treatment of immune and proliferative disorders.

(10) Pissot-Soldermann, C., Gerspacher, M., Furet, P., Gaul, C., Holzer, P., McCarthy, C., Radimerski, T., Regnier, C. H., Baffert, F., Drueckes, P., Tavares, G. A., Vangrevelinghe, E., Blasco, F., Ottaviani, G., Ossola, F., Scesa, J., and Reetz, J. (2010) Discovery and SAR of potent, orally available 2,8-diarylquinoxalines as a new class of JAK2 inhibitors. Bioorganic Med. Chem. Lett. 20, 2609-2613.

(11) Baffert, F., Regnier, C. H., De Pover, A., Pissot-Soldermann, C., Tavares, G. A., Blasco, F., Brueggen, J., Chene, P., Drueckes, P., Erdmann, D., Furet, P., Gerspacher, M., Lang, M., Ledieu, D., Nolan, L., Ruetz, S., Trappe, J., Vangrevelinghe, E., Wartmann, M., Wyder, L., Hofmann, F., and Radimerski, T. (2010) Potent and Selective Inhibition of Polycythemia by the Quinoxaline JAK2 Inhibitor NVP-BSK805. Mol. Cancer Ther. 9, 1945-1955.

(12) Ertl, P., Rohde, B., and Selzer, P. (2000) Fast calculation of molecular polar surface area as a sum of fragment-based contributions and its application to the prediction of drug transport properties. J. Med. Chem. 43, 3714-3717.

(13) Buckley, D. L., Raina, K., Darricarrere, N., Hines, J., Gustafson, L. J., Smith, I. E., Miah, A. H., 
Harling, J. D., and Crews, C. M. (2015) HaloPROTACS: Use of Small Molecule PROTACs to Induce Degradation of HaloTag Fusion Proteins. ACS Chem. Biol. 10, 1831-1837.

(14) Churcher, I. (2018) Protac-Induced Protein Degradation in Drug Discovery: Breaking the Rules or Just Making New Ones? J. Med. Chem. 61, 444-452.

(15) Lipinski, C. A., Lombardo, F., Dominy, B. W., and Feeney, P. J. (1997) Experimental and computational approaches to estimate solubility and permeability in drug discovery and development settings. Adv. Drug Deliv. Rev. 23, 3-25.

(16) Kelder, J., D. J. Grootenhuis, P., M. Bayada, D., P. C. Delbressine, L., and Ploemen, J.-P. (1999) Polar molecular surface as a dominating determinant for oral absorption and brain penetration of drugs. Pharm. Res. 16, 1514-1519.

(17) Doak, B. C., Over, B., Giordanetto, F., and Kihlberg, J. (2014) Oral druggable space beyond the rule of 5: Insights from drugs and clinical candidates. Chem. Biol. 21, 1115-1142.

(18) Degoey, D. A., Chen, H. J., Cox, P. B., and Wendt, M. D. (2018) Beyond the Rule of 5: Lessons Learned from AbbVie's Drugs and Compound Collection. J. Med. Chem. 61, 2636-2651.

(19) Matsson, P., and Kihlberg, J. (2017) How Big Is Too Big for Cell Permeability? J. Med. Chem. 60, 1662-1664.

(20) Young, R. J., Green, D. V. S., Luscombe, C. N., and Hill, A. P. (2011) Getting physical in drug discovery II: The impact of chromatographic hydrophobicity measurements and aromaticity. Drug Discov. Today 16, 822-830.

(21) Harling, J. D., and Smith, I. E. D. (2016) Preparation of IAP E3 ligase directed proteolysis targeting chimeric molecules.

(22) Galdeano, C., Gadd, M. S., Soares, P., Scaffidi, S., Van Molle, I., Birced, I., Hewitt, S., Dias, D. M., and Ciulli, A. (2014) Structure-guided design and optimization of small molecules targeting the protein-protein interaction between the von hippel-lindau (VHL) E3 ubiquitin ligase and the hypoxia inducible factor (HIF) alpha subunit with in vitro nanomolar affinities. J. Med. Chem. 57, 8657-8663.

(23) Krönke, J., Udeshi, N. D., Narla, A., Grauman, P., Hurst, S. N., McConkey, M., Svinkina, T., Heckl, D., Comer, E., Li, X., Ciarlo, C., Hartman, E., Munshi, N., Schenone, M., Schreiber, S. L., Carr, S. A., and Ebert, B. L. (2014) Lenalidomide Causes Selective Degradation of IKZF1 and IKZF3 in Multiple Myeloma Cells. Science (80-. ). 343, 301-306.

(24) Thorarensen, A., Banker, M. E., Fensome, A., Telliez, J.-B., Juba, B., Vincent, F., Czerwinski, R. M., and Casimiro-Garcia, A. (2014) ATP-mediated kinome selectivity: The missing link in understanding the contribution of individual JAK kinase isoforms to cellular signaling. ACS Chem. Biol. 9, 1552-1558.

(25) Mateus, A., Gordon, L. J., Wayne, G. J., Almqvist, H., Axelsson, H., Seashore-Ludlow, B., Treyer, A., Matsson, P., Lundbäck, T., West, A., Hann, M. M., and Artursson, P. (2017) Prediction of intracellular exposure bridges the gap between target- and cell-based drug discovery. Proc. Natl. Acad. Sci. 114, E6231-E6239.

(26) (2018) Proteinatlas.org.

(27) Bondeson, D. P., Mares, A., Smith, I. E. D., Ko, E., Campos, S., Miah, A. H., Mulholland, K. E., Routly, N., Buckley, D. L., Gustafson, J. L., Zinn, N., Grandi, P., Shimamura, S., Bergamini, G., FaelthSavitski, M., Bantscheff, M., Cox, C., Gordon, D. A., Willard, R. R., Flanagan, J. J., Casillas, L. N., Votta, B. J., den Besten, W., Famm, K., Kruidenier, L., Carter, P. S., Harling, J. D., Churcher, I., and Crews, C. 
M. (2015) Catalytic in vivo protein knockdown by small-molecule PROTACs. Nat. Chem. Biol. 11, 611617.

(28) Ungureanu, D., Saharinen, P., Junttila, I., Hilton, D. J., and Silvennoinen, O. (2002) Regulation of Jak2 through the Ubiquitin-Proteasome Pathway Involves Phosphorylation of Jak2 on Y1007 and Interaction with SOCS-1. Mol. Cell. Biol. 22, 3316-3326.

(29) Emanuele, M. J., Elia, A. E. H., Xu, Q., Thoma, C. R., Izhar, L., Leng, Y., Guo, A., Chen, Y. N., Rush, J., Hsu, P. W. C., Yen, H. C. S., and Elledge, S. J. (2011) Global identification of modular cullin-RING ligase substrates. Cell 147, 459-474.

(30) Udeshi, N. D., Svinkina, T., Mertins, P., Kuhn, E., Mani, D. R., Qiao, J. W., and Carr, S. A. (2013) Refined Preparation and Use of Anti-diglycine Remnant (K- $\varepsilon-G G)$ Antibody Enables Routine Quantification of 10,000s of Ubiquitination Sites in Single Proteomics Experiments. Mol. Cell. Proteomics 12, 825-831.

(31) Wagner, S. A., Beli, P., Weinert, B. T., Nielsen, M. L., Cox, J., Mann, M., and Choudhary, C. (2011) A Proteome-wide, Quantitative Survey of In Vivo Ubiquitylation Sites Reveals Widespread Regulatory Roles. Mol. Cell. Proteomics 10, M111.013284.

(32) Sarraf, S. A., Raman, M., Guarani-Pereira, V., Sowa, M. E., Huttlin, E. L., Gygi, S. P., and Harper, J. W. (2013) Landscape of the PARKIN-dependent ubiquitylome in response to mitochondrial depolarization. Nature 496, 372-376.

(33) Zinn, N. (2017) CellZome Unpublished Work. Cellzome GmbH, GlaxoSmithKline.

(34) Behrmann, I., Smyczek, T., Heinrich, P. C., Schmitz-Van De Leur, H., Komyod, W., Giese, B., Müller-Newen, G., Haan, S., and Haan, C. (2004) Janus kinase (Jak) subcellular localization revisited: The exclusive membrane localization of endogenous Janus kinase 1 by cytokine receptor interaction uncovers the Jak.receptor complex to be equivalent to a receptor tyrosine kinase. J. Biol. Chem. 279, 35486-35493.

(35) Gadd, M. S., Testa, A., Lucas, X., Chan, K. H., Chen, W., Lamont, D. J., Zengerle, M., and Ciulli, A. (2017) Structural basis of PROTAC cooperative recognition for selective protein degradation. Nat. Chem. Biol. 13, 514-521.

(36) Bondeson, D. P., Smith, B. E., Burslem, G. M., Buhimschi, A. D., Hines, J., Jaime-Figueroa, S., Wang, J., Hamman, B. D., Ishchenko, A., and Crews, C. M. (2018) Lessons in PROTAC Design from Selective Degradation with a Promiscuous Warhead. Cell Chem. Biol. 25, 78-87.e5.

(37) Huang, H. T., Dobrovolsky, D., Paulk, J., Yang, G., Weisberg, E. L., Doctor, Z. M., Buckley, D. L., Cho, J. H., Ko, E., Jang, J., Shi, K., Choi, H. G., Griffin, J. D., Li, Y., Treon, S. P., Fischer, E. S., Bradner, J. E., Tan, L., and Gray, N. S. (2018) A Chemoproteomic Approach to Query the Degradable Kinome Using a Multi-kinase Degrader. Cell Chem. Biol. 25, 88-99.e6.

(38) Smith, B. E., Wang, S. L., Jaime-Figueroa, S., Harbin, A., Wang, J., Hamman, B. D., and Crews, C. M. (2019) Differential PROTAC substrate specificity dictated by orientation of recruited E3 ligase. Nat. Commun. 10, 1-13.

(39) Douglass, E. F., Miller, C. J., Sparer, G., Shapiro, H., and Spiegel, D. A. (2013) A comprehensive mathematical model for three-body binding equilibria. J. Am. Chem. Soc. 135, 6092-6099. 